\title{
Permanências e mudanças na expansão dos serviços postais em Santa Catarina (1900-1930)
}

\author{
Permanences and changes in the expansion of postal services in Santa \\ Catarina (1900-1930)
}

\author{
Gabriel Crozetta Mazon e Alcides Goularti Filho*
}

\begin{abstract}
Resumo: Este artigo tem como objetivo descrever e analisar a expansão dos serviços postais em Santa Catarina entre 1900 e 1930 abordando suas mudanças e permanências. As categorias de análises são: camadas geoeconômicas, adensamento do Estado no território e sistema regional de economia. Além das considerações finais, o artigo está divido em três tópicos: a) combinação e sobreposição dos serviços postais, que traz uma breve contextualização da trajetória dos Correios no Brasil e apresenta as categorias de análise; b) transportes e comunicações na definição do território, onde apresenta um histórico das vias de comunicação e dos meios de transporte em Santa Catarina na formação dos limites territoriais; e, por fim, c) a expansão dos serviços postais em Santa Catarina, que está dividido em quatro itens: agência e linhas postais, movimento postal, movimento financeiro e trabalhadores.
\end{abstract}

Palavras-chave: História de Empresas; Serviços Postais; Correios

\begin{abstract}
This article aims to describe and analyze the expansion of postal services in Santa Catarina between 1900 and 1930 addressing their changes and permanencies. The categories of analysis are: geoeconomic layers, and state subdivision in the territory and regional economic system. In addition to the final considerations, the article is divided into three topics: a) combination and overlapping of postal services, which brings a brief contextualization of the trajectory of postal services in Brazil and presents the categories of analysis; b) transport and communications in the definition of the territory, which presents a history of the communications routes and means of transport in Santa Catarina in the formation of the territorial limits; and finally c) expansion of postal services in Santa Catarina, which is divided into four items: agency and postal lines, postal movement, financial movement and workers.
\end{abstract}

Keywords: Business History; Postal Services; Post Offices

JEL Code: N7; N9

\footnotetext{
* Respectivamente, mestrando no Programa de Pós-Graduação em Desenvolvimento Socioeconômico da Universidade do Extremo Sul Catarinense Universidade do Extremo Sul Catarinense (UNESC). E-mail: gabrielcmazon@gmail.com. Orcid: https://orcid.org/0000-0002-8326-0734; e professor do Programa de Pós-Graduação em Desenvolvimento Socioeconômico da Universidade do Extremo Sul Catarinense (UNESC). E-mail: agf@unesc.net. Orcid: https://orcid.org/0000-0002-0808-4486.
} 


\section{Introdução: combinação e sobreposição dos serviços postais}

A predominância dos estudos acadêmicos sobre a formação dos sistemas nacionais de economia gira em torno da expansão dos transportes modernos, os quais são definidos como elementos impulsionadores do desenvolvimento das forças produtivas. Os investimentos na construção, reparos e melhorias nas vias de transportes férreo, fluvial, marítimo e terrestre, em boa medida, partem de demandas dos fluxos mercantis, da expansão populacional, das estratégias militares e da definição e ocupação do território. Numa mesma proporção, esses investimentos também atendem às necessidades de modernização dos meios de comunicação e da difusão das informações, formando uma unidade indissolúvel: transportes e comunicações.

Assim como os transportes, as comunicações também foram determinantes - no século XIX, representados pelos correios e telégrafos - na definição e ocupação do território e na formação de mercados. A disponibilidade de meios de comunicação fomentou o crescimento da produção e dos fluxos mercantis, promoveu a expansão demográfica, aproximou pessoas, atualizou conhecimento e permitiu maior acesso às informações. A existência de caminhos e estradas permitia às regiões mais afastadas dos centros urbanos o acesso ao comércio e, ao mesmo tempo, colaborava com a manutenção do seu povoamento, tornando a vida social e material mais complexa. Nesse processo de expansão econômica e social, surgem os serviços postais - por meio da abertura de agências de correios e linhas postais - transportando correspondências, encomendas, objetos de valores e mercadorias em geral.

Em função da sua dimensão continental, até meados do século XX, o Brasil manteve uma distribuição populacional muito dispersa com povoamento mais concentrado no litoral. Essa é uma característica herdada do período colonial, reposta no Império e no início da República. Segundo Caio Prado Júnior (1996, p. 36):

A sua distribuição pelo território da colônia é (...), grandemente irregular. Núcleos apenas, alguns bastante densos, mas separados uns dos outros por largos vácuos de povoamento ralo, se não inexistente. O seu aspecto geral, guardadas naturalmente as devidas proporções quantitativas, é mais ou menos o mesmo de hoje. Há uma flagrante semelhança entre a distribuição do povoamento naquele princípio do século XIX e a de nossos dias [anos de 1940]. 
Mesmo com os senderos traçados pelas comunidades indígenas, foi necessária a abertura de novos caminhos - desenhados pelas bandeiras, entradas e monções - para permitir o acesso de pessoas e mercadorias às regiões mais longínquas deste imenso continente. Sobrepondo-se a esse mosaico de caminhos, foi sendo desenhado o mapa viário brasileiro do século XX. Ao mesmo tempo em que as estradas eram abertas para a integração nacional, também eram utilizadas para a passagem dos estafetas que circulavam nas linhas postais. A modernização dos transportes favoreceu a expansão das comunicações, mas também a necessidade de melhorias nas comunicações levou ao aperfeiçoamento nos transportes. Meios de transporte e comunicação partilham estruturas semelhantes, como estradas, ferrovias, rios navegáveis e outras modalidades. Ambos formam e fazem parte do sistema nacional de economia.

Estudar as comunicações possibilita entender a constituição das diversas comunidades de sociedades na contemporaneidade. Dentro do processo de formação de uma nação, é difícil hierarquizar a centralidade que as comunicações assumem, pois ela compartilha com outras estruturas logísticas o papel determinante na constituição do sistema nacional de economia. A combinação e a sobreposição dessas estruturas logísticas formam camadas que assumem um caráter geográfico e econômico que fazem interagir território e fluxos, as quais denominamos de camadas geoeconômicas. Neste artigo, os serviços postais são parte constitutiva dessas camadas, que, simultaneamente, combinam com os transportes, telégrafos, energia, sistema de abastecimento de água, gás, fibra ótica e outros.

As camadas geoeconômicas estão sobrepostas num território. Território é uma totalidade que condensa passado e presente, real e virtual em um mesmo instante. Sua ocupação, definição e construção contínua são comandadas, em larga medida, pelo Estado em um processo de adensamento de suas funções. A ocupação torna-se condição necessária para fazer existir o Estado; a definição delimita a área de atuação do Estado; e a construção contínua ocorre por meio da intervenção estatal, que penetra em todos os poros possíveis do território. A combinação desses três movimentos resulta em um adensamento do Estado no território. Adensar significa marcar presença, ir até o local, conectar partes, estabelecer relações de poder, controlar fixos e fluxos e criar condições para a reprodução da existência do próprio território (GOULARTI FILHO, 2017). 
A instituição dos Correios faz parte da fundação da nação brasileira desde a declaração da Independência em 1822. A circulação de informação, anúncios e comunicados oficiais sempre foi atribuição dos Correios. Ao longo de sua existência como instituição balizar das comunicações, os Correios passaram por várias reformas. $\mathrm{O}$ primeiro, no começo do Império, por meio do Decreto de 5 de março de 1829, que criou a Administração Geral dos Correios (BRASIL, 1877). Durante o período regencial, foi aprovado o Decreto n. ${ }^{\circ} 255$, de 29 de novembro de 1842, que adotou o selo postal nas correspondências, instituiu o adiantamento do pagamento pelos portes de cartas e criou o quadro funcional de carteiros

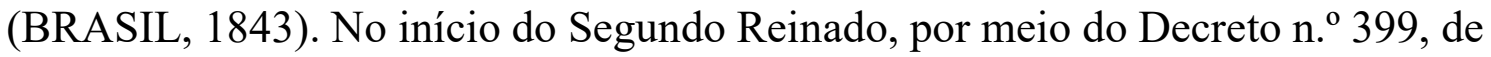
21 de dezembro de 1844, foi iniciada uma ampla reforma nos Correios, quando foram aprovados subsídios aos serviços postais e criadas as administrações provinciais (BRASIL, 1845). Esses dois decretos constituíram-se na pedra angular da organização dos correios brasileiros. No final do Império, houve uma nova reforma, por meio do Decreto n. ${ }^{\circ}$ 9.912-A, de 26 de março de 1888, que ampliou e garantiu o monopólio dos serviços postais ao Estado (BRASIL, 1889). O monopólio dos serviços postais foi reforçado pelo novo regulamento aprovado pelo Decreto n. ${ }^{\circ} 2.230$, de 10 de fevereiro de 1896 , cujo Art. $3^{\circ}$ previa que a União tivesse o monopólio dos transportes e distribuição de cartas e correspondências de quaisquer naturezas, além da confecção, emissão e venda de selos, cartas-bilhetes e bilhetes postais (BRASIL, 1897). Por fim, a Lei n..$^{\circ} 4.273$, de $1^{\circ}$ de fevereiro de 1921, reformou e ampliou a organização dos serviços, com destaque para a melhoria das condições de trabalho dos servidores dos correios.

Os serviços postais se diferenciam de outros meios de comunicação, como o telegráfico e a telefonia, pelos seguintes pontos:

$\checkmark$ Menor grau de investimento técnico.

$\checkmark$ Maior capacidade de assimilação de novas modalidades de transporte.

$\checkmark$ Alta mobilidade dos serviços na utilização de vários meios de transportes.

$\checkmark$ Maior abrangência social, estando economicamente acessível a toda a população.

$\checkmark$ Facilidade em incorporar as características regionais de ordem cultural e social. 


\section{Transportes e comunicações na definição do território:}

Podemos pensar a ocupação e definição do território catarinense em três momentos. O primeiro ocorreu após a Restauração Portuguesa (1640), com a retomada da ocupação do litoral sul da colônia com a fundação das vilas de São Francisco (1645), Desterro (1650) e Laguna (1676) pelos vicentistas e açorianos. O segundo ocorreu com a abertura dos caminhos das tropas que partiam da Colônia do Sacramento à região das minas pelos paulistas, passando pelo atual planalto serrano catarinense, que resultou na fundação de Lages (1766). Por fim, o terceiro momento se deu a partir dos meados do século XIX com as frentes de expansão nos Campos de Palmas em direção à fronteira com a Argentina.

Inicialmente a colonização açoriana era restrita ao litoral, constituindo pequenas propriedades com a predominância de agricultura de subsistência e pesca artesanal. No planalto de Lages, havia a pecuária extensiva, por onde passavam os tropeiros, os quais se estabeleciam em pontos de invernadas junto às estâncias e fundaram pequenas comunidades e vilas. Desterro, localizada na Ilha de Santa Catarina, desenvolveu-se como uma base de defesa militar, enquanto São Francisco e Laguna configuravam-se como entrepostos comerciais para as expansões portuguesas ao sul da colônia (COELHO, 1856).

Após a Lei de Terras de 1850, o Império passou a dar mais atenção à colonização estrangeira, colocando à disposição as terras devolutas para demarcação dos núcleos populacionais de imigrantes. Em Santa Catarina, foram colonizadas, por imigrantes europeus, terras nos vales dos rios Tubarão e Urussanga, planalto norte, litoral norte e Vale do Itajaí, onde fundaram prósperas comunidades baseadas na pequena produção mercantil. Os principais núcleos coloniais, como Urussanga, Criciúma, Blumenau, Brusque, Joinville e São Bento do Sul constituíram-se em centros irradiadores de novos povoamentos para o interior colonial catarinense (MATTOS, 1917).

A colonização no Vale do Rio do Peixe (Meio-Oeste) e no Oeste catarinense ocorreu noutro momento dentro do processo de povoamento do Brasil meridional. A rota de expansão em direção ao Oeste catarinense já estava aberta com a ocupação esparsa dos Campos de Palmas pelas fazendas de pecuária extensiva e pela fundação da Colônia Militar de Chapecó em 1882. Nas primeiras décadas do século XX, impulsionado por companhias privadas de colonização, o Grande Oeste catarinense foi sendo povoado por migrantes advindos do Rio Grande do 
Sul, que reproduziam na região o sistema de produção herdado das velhas colônias. Esse movimento de colonização faz parte das frentes pioneiras de expansão em direção ao Centro-Oeste brasileiro (PERFEITO, 1950; XAVIER, 1944).

Um processo de caráter marcadamente capitalista, a colonização do Grande Oeste catarinense foi responsável por expandir o território barriga-verde até a fronteira com a Argentina. Caçador, Joaçaba, Concórdia, Chapecó e São Miguel do Oeste são exemplos de cidades fundadas pelas frentes pioneiras. Mesmo com certa autonomia relativa, na reprodução da sua existência, a abertura de estradas, a construção de ferrovias, a extensão da rede de telégrafos e a inauguração de linhas postais (camadas geoeconômicas) formaram no Oeste catarinense uma rede de comércio e integraram os diversos sistemas regionais à economia estadual e nacional.

Dentro do movimento de formação da economia catarinense, a exemplo de outras regiões, os portos, a navegação (fluvial, marítima e lacustre), as ferrovias e as estradas atuaram como protagonistas na construção das estruturas econômicas regionais. Os portos de São Francisco, Desterro (Florianópolis) e Laguna, além de operarem como entrepostos comerciais dos fluxos mercantis para suas hinterlands, também serviram como porta de entrada dos imigrantes. Com relação ao transporte ferroviário, a primeira ferrovia construída no território catarinense data de 1880, a Estrada de Ferro Dona Tereza Cristina (EFDTC) entre Laguna, Tubarão e Lauro Müller. No Meio-Oeste, nas margens do rio do Peixe, em 1910, foi concluído o trecho da Estrada de Ferro São Paulo-Rio Grande (EFSPRG), integrando o interior do país entre Itararé (SP) e Santa Maria (RS). O ramal da EFSPRG, entre o porto de São Francisco do Sul e Porto União, no Planalto Norte, foi concluído em 1917. No vale do Itajaí, a Estrada de Ferro Santa Catarina (EFSC) foi inaugurada em 1909 com um pequeno trecho entre Blumenau e Indaial, e, ao longo das décadas seguintes, estendeu seus trilhos em direção à Leste (Itajaí) e à Oeste (São João da Agrolândia) (GOULARTI FILHO, 2013).

No transporte fluvial, operavam a navegação entre Itajaí e Blumenau - por meio da Companhia de Navegação Fluvial a Vapor Itajahy-Blumenau -, a navegação no Planalto Norte, na divisa com o Paraná, entre os rios Negro e Iguaçu, e o canal de navegação entre Laguna e Jaguaruna. Portanto, uma parte considerável do território catarinense não era atendida por ferrovia ou navegação, restando a utilização dos caminhos. As cidades litorâneas se conectavam pela Estrada do 
Litoral; entre Laguna e Lages havia dois caminhos, a Estrada do Imaruí e a Estrada do Tubarão, ambas cruzavam a Serra Geral; entre o Vale do Itajaí e o planalto serrano, havia a Estrada de Blumenau a Curitibanos, que integrava dois mundos, os colonos e os tropeiros; no Planalto Norte, a moderna Estrada Dona Francisca colocava Joinville em contato direto com o complexo ervateiro até Rio Negro; São Francisco do Sul conectava-se com o Planalto de Curitiba desde o século XVIII pela Estrada de Três Barras; todo o Planalto Serrano era cortado pelo Caminho Viamão-Sorocaba e no trecho entre Curitibanos e Rio Negro, onde a floresta era mais densa, realizou-se uma série de obras, para criar condições de trafegabilidade para as tropas, que resultaram na abertura da Estrada da Mata; o Planalto Serrano se comunicava com o Campo de Palmas, por meio da estrada de Campos Novos a Palmas que cruzava todo território em litígio com o Paraná; no Extremo Oeste, em terras ainda disputadas, o caminho das Missões (RS) a Guarapuava (PR) atravessa os rios Uruguai, Chapecó e Chapecózinho, que mais tarde serviu de base para a consolidação da Colônia Militar de Chapecó; e, por fim, a mais aclamada pelo governo provincial, a Estrada de Lages, que aproximava a capital do interior e se constituiu na mais imponente obra de integração rodoviária de Santa Catarina.

No século XIX e início do XX, a pouca presença de transportes modernos em Santa Catarina, representados pelas ferrovias e pela navegação a vapor, não impediu que as diversas vilas e cidades se comunicassem entre si e com centros maiores. Mesmo com dificuldade de acesso mais rápido a determinadas localidades, os caminhos e as estradas eram comumente utilizados pelas pessoas nos mais distantes rincões deste país. Eram por essas vias que circulavam pessoas, mercadorias e serviços postais.

No século XIX, houve uma expansão contínua dos serviços postais no Brasil, com maior aceleração pós-1875, cujo movimento está associado ao processo de modernização e urbanização da sociedade brasileira. Analisando a expansão dos serviços dos correios em Santa Catarina durante o século XIX, Goularti Filho (2017) identificou dois movimentos concomitantes. O primeiro caracterizou-se por uma litoralização direcionada com a abertura de agências e linhas postais entre Laguna e São Francisco, passando por Desterro e Itajaí, e, mais tarde, pós-1870, como entrada até Blumenau e Joinville. O acesso a essas cidades era realizado por meio da navegação marítima e fluvial (rios Cachoeira e ItajaíAçu). O segundo movimento se deu por meio de uma interiorização truncada com 
a expansão dos serviços postais no "sertão da terra firme" e até Lages, tendo como via de acesso a Estrada de Lages, que seguia os vales dos rios Maruim e Cubatão.

Se no século XIX a interiorização dos serviços postais enfrentou grandes dificuldades para chegar até Lages e Campos Novos, no século seguinte, a interiorização rumo ao Planalto Norte e Grande Oeste assumiu formas de uma disseminação acelerada. O território contestado, que englobava o atual Planalto Norte e Oeste catarinense e o Vale do Chopim no Paraná - que era disputado por Santa Catarina e Paraná - passou a ser uma área estratégica para o governo catarinense, que almejava garantir seu território até a fronteira com a Argentina. A presença de instituições de fornecimento de serviço público nessa nova área tinha como objetivo passar à população a figura de um Estado presente, que vai se adensando no território e fazendo parte da vida cotidiana. A fundação de agências dos correios e de linhas postais nesse imenso território corroborava com esse objetivo.

\section{Expansão dos serviços postais em Santa Catarina}

Durante a Primeira República, assistimos no Brasil a um processo de expansão das manufaturas de baixa incorporação tecnológica, a formação dos complexos agrorregionais e a rápida urbanização das capitais brasileiras. A combinação desses três movimentos exigia a presença do Estado realizando investimentos nas áreas de transportes e comunicações. A expansão e a dinamização da economia brasileira nesse período de acelerada modernização obrigavam o Estado a intervir direta ou indiretamente no mercado para destravar gargalos que dificultavam o livre desenvolvimento das forças produtivas.

Do final do século XIX até 1930, originaram-se e se expandiram em Santa Catarina as atividades industriais da madeira (Vale do Itajaí), alimentos (Vale do Itajaí, Meio-Oeste e Joinville), carvão (Sul, no vale dos rios Tubarão e Urussanga), madeira e erva-mate (Norte e Planalto Norte) e têxtil (Vale do Itajaí e Joinville). Em cada região essas atividades econômicas assumiram a liderança no processo de acumulação e combinavam com o comércio e a manufatura local, representadas pela pequena produção mercantil de origem colonial imigrante (GOULARTI FILHO, 2016). Foi sobre essa base econômica que se assentaram as camadas geoeconômicas dos transportes e das comunicações. A combinação dessas indústrias originárias com as camadas geoeconômicas forma o sistema regional de 
economia, que, em Santa Catarina, ao longo do século XX, assumiu o caráter de uma economia especializada, diversificada e integrada.

Para analisarmos a trajetória dos serviços postais em Santa Catarina entre 1900 e 1930, vamos abordar quatro tópicos: abertura de agências e linhas postais; movimento postal; resultado financeiro; e as relações de trabalho.

\subsection{Agências dos correios e linhas postais na formação da unidade territorial}

Neste item analisaremos a abertura de novas agências dos correios e de linhas postais em Santa Catarina como parte integrante da constituição das camadas geoeconômicas na formação dos sistemas regionais de economia. Observando a expansão dos serviços postais em Santa Catarina entre 1900 e 1930, a Tabela 1 nos revela que, no começo do século XX, houve um menor aumento no número de agências e linhas. Ressalta-se que o acréscimo no número de agências é maior do que o de linhas, cuja variação se dava mais em função do seu alongamento a partir da extensão de uma linha existente (DIRETORIA-GERAL DO CORREIOS, 1900-1930). Nos anos de 1920, podemos verificar um crescimento dos sistemas regionais catarinenses fundados na erva-mate, madeira, carvão, têxtil e alimentos, o que exigiu maior alcance das estruturas de serviços públicos como os telégrafos e correios. É nesse período, pós-conflito do Contestado e a definitiva demarcação do território catarinense, que podemos observar a maior interiorização dos serviços postais, com a abertura de agências e prolongamento de linhas. 
Tabela 1 - Evolução do número de agências dos Correios existentes e abertos e de linhas postais em Santa Catarina (1900-1930)

\begin{tabular}{cc|cc|cc}
\hline Ano & $\begin{array}{c}\text { Agências } \\
\text { abertas }\end{array}$ & Ano & $\begin{array}{c}\text { Total de } \\
\text { agências }\end{array}$ & Ano & $\begin{array}{c}\text { Total de linhas } \\
\text { postais }\end{array}$ \\
\hline 1901 & 3 & 1900 & 45 & 1900 & 30 \\
1902 & 1 & 1901 & 48 & 1901 & 30 \\
1904 & 2 & 1907 & 68 & 1909 & 46 \\
1905 & 3 & 1908 & 67 & 1911 & 68 \\
1906 & 3 & 1909 & 71 & 1912 & 69 \\
1907 & 2 & 1911 & 72 & 1918 & 81 \\
1909 & 3 & 1912 & 78 & 1920 & 99 \\
1918 & 6 & 1917 & 89 & 1921 & 107 \\
1919 & 4 & 1918 & 92 & 1922 & 107 \\
1920 & 7 & 1920 & 119 & 1923 & 107 \\
1921 & 4 & 1921 & 118 & 1924 & 121 \\
1923 & 3 & 1922 & 123 & 1925 & 122 \\
1924 & 5 & 1925 & 131 & 1926 & 122 \\
1925 & 2 & 1926 & 132 & 1927 & 138 \\
1926 & 2 & 1927 & 150 & 1928 & 147 \\
1927 & 12 & 1928 & 171 & 1930 & - \\
1928 & 23 & 1929 & 189 & - & - \\
1929 & 18 & 1930 & 198 & - & - \\
1930 & 4 & - & - & - & \\
\hline
\end{tabular}

Fonte: Relatórios da Diretoria-Geral do Correios, 1900-1930 (série completa).

Até 1918, houve uma concentração litorânea e colonial (Leste, Sul, Vale do Itajaí e Norte) com abertura dos serviços nas comunidades pesqueiras e nos pequenos núcleos coloniais. No litoral, foram abertas as agências de Estreito, Santíssima Trindade, Itapoá e Porto dos Ganchos. Nas áreas de colonização, os serviços foram disponibilizados para as comunidades de Braço do Norte, Ibirama, São Pedro de Alcântara, Corupá, Rancho Queimado e Pomerode. Houve também a abertura de uma agência no Planalto Serrano, na localidade de Painel e Socorro. $\mathrm{Na}$ primeira década do século XX, ao todo, foram abertas 14 novas agências (Quadro 1 e Anexo 1).

Pós-1918 esse movimento foi reforçado, porém inicia-se um novo processo de disseminação acelerada rumo ao Planalto Norte e Grande Oeste catarinense (Meio-Oeste e Oeste), área de avanço das frentes pioneiras, da colonização privada e da economia da madeira (Quadro 1 e Anexo 1). No ano de 1918, no Meio-Oeste, entraram em operação as agências de Rio das Antas, Rio Preto, Rio Capinzal, Rio 
do Peixe, Barra do Leão, Pinheiro Preto e Barra Fria, além de uma agência exclusiva para a EFSPRG.

\section{Quadro 1 - Agências dos Correios abertas em Santa Catarina por região} (1900-1930)

\begin{tabular}{|l|c|}
\hline \multicolumn{1}{|c|}{ Região } & Agências \\
\hline Leste (Grande Florianópolis) & 18 \\
\hline Vale do Itajaí & 18 \\
\hline Planalto Norte & 17 \\
\hline Sul & 15 \\
\hline Planalto Serrano & 13 \\
\hline Meio-Oeste & 8 \\
\hline Norte & 4 \\
\hline Oeste & 3 \\
\hline Total & 96 \\
\hline
\end{tabular}

Fonte: Relatórios da Diretoria-Geral do Correios, 1900-1930 (série completa).

No Planalto Norte, já estava em formação o complexo ervateiro, de grande relevância para as exportações e para a economia estadual, que demandava a construção acelerada de uma estrutura logística de transportes e comunicações. Em 1917, foi inaugurado o trecho final do ramal ferroviário da EFSPRG entre São Francisco e Porto União, passando por Mafra, Três Barras e Canoinhas. Outra modalidade de transporte utilizada na região era a navegação pelos rios Negro e Iguaçu entre Mafra e Porto União. A Estrada Dona Francisca, cujas obras foram finalizadas no final do século XIX, colocava o Planalto Norte em contato direto com o litoral catarinense. Sobre essa base de transportes (ferrovia, navegação e estrada) se estabeleceram os serviços dos Correios e, mais tarde, dos telégrafos. Ressalta-se também que após a assinatura do Acordo de Limites em 1916, o governo catarinense intensificou suas ações no sentido de garantir a demarcação da divisa territorial. Para isso, foram criadas, entre 1918 e 1920, agências dos Correios em Três Barras, Vallões, Mafra, Calmon, Porto União, Lagoa de Canoinhas, Rio Negrinho e Encruzilhada. Traçado o limite, criaram-se agências no sentido interior em direção ao Sul, como Lucena (Itaiópolis), Nova Galícia e Caçador. Em direção a Oeste, no ano de 1919 foi inaugurada a agência de Passo de Bormann, no atual município de Chapecó (Anexo 1). E próximo à fronteira com 
a Argentina, no Extremo Oeste catarinense, estabeleceu-se, em 21 de dezembro de 1926, a agência de Mondaí (à margem do rio Uruguai) (A REPÚBLICA, 1926).

Quando observamos com mais detalhes as datas de abertura de agências, fica evidente, no triênio de 1927, 1928 e 1929, um aumento significativo no número de novas agências, que corresponde a 49,5\% das criadas no período analisado, sendo em sua maioria no Planalto Norte, próximo à divisa com o Paraná (Anexo 1). Cabe ressaltar que, de 1926 a 1930, o catarinense Victor Konder era ministro da Viação e Obras Públicas, enquanto seu irmão, Adolpho Konder, exercia o cargo de governador de Santa Catarina.

A Administração dos Correios na capital, quando não atendia rapidamente certa localidade, recebia ofício de dirigentes e autoridades solicitando e justificando a conveniência da abertura de uma agência. No jornal A República, estão noticiados alguns pedidos, como nos dias 20 de dezembro de 1918, 8 de maio de 1919 e 21 de janeiro de 1920, por exemplo, podem ser lidos pedidos dirigidos à Administração de Santa Catarina, na capital, para instalação das agências em Três Barras e Porto União. Como justificativa para abertura dessas agências, as autoridades locais alegavam que suas vilas necessitavam dos serviços postais por estarem se tornando "prósperas" (A REPÚBLICA, 1918; A REPÚBLICA, 1919; A REPÚBLICA, 1920).

A expansão dos serviços postais para o Oeste e Extremo Oeste catarinense foi posterior à expansão para as demais regiões, pois, no começo do século XX, o território ainda estava em litígio com o Paraná. Desde a "descoberta" dos Campos de Palmas (primeira metade do século XIX), foram se estabelecendo nesse território fazendas para a pecuária extensiva e o extrativismo florestal de madeira e erva-mate (BANDEIRA, 1851). Nas duas primeiras décadas do século XX, chegaram à região contestada os agentes especuladores de companhias privadas que "adquiriam” terras públicas e privadas para colonização. Após o fim da Guerra do Contestado e a assinatura do Acordo de Limites, tanto no Planalto Norte como no Grande Oeste catarinense, foram sendo realizados novos investimentos em serviços públicos (estradas, correios, telégrafos, escolas, segurança, hospitais) para assentar as frentes pioneiras que marchavam em busca do eldorado. Concomitantemente à expansão da estrutura viária, os serviços postais começaram a se estabelecer nas novas vilas e cidades que surgiam no Oeste catarinense, chegando até a fronteira com a Argentina. 
Com relação às linhas postais em Santa Catarina, o movimento de abertura de novos trechos acompanhou os mesmos passos da fundação das agências dos correios. Do litoral para o interior, passando pelas áreas coloniais, seguindo em direção ao Planalto Norte serrano até a sua extensão definitiva rumo ao Grande Oeste. Há uma estreita relação entre a utilização pelos estafetas e carteiros das modalidades de transportes disponíveis e a velocidade da entrega das encomendas postais. Inicialmente, utilizava-se o transporte a cavalo, que fazia percursos de curta e longa distância, no entanto, com o advento dos transportes modernos, a lista de modalidades utilizadas pelos Correios agregou a ferrovia e a navegação. A partir dos anos de 1920, a proliferação do sistema rodoviário e o uso do automóvel impactaram diretamente os serviços dos agentes dos Correios com a formação de frotas de veículos para a entrega das encomendas (DIRETORIA-GERAL DO CORREIOS, 1920-1930) (Anexo 2). Por fim, o advento da aviação acelerou ainda mais a entrega das encomendas com a utilização dos correios aéreos. Portanto, há uma estreita relação entre a modernização das modalidades de transportes e o melhoramento dos serviços postais. Quando novas modalidades de transportes eram introduzidas numa determinada região, em seguida começavam a ser utilizadas pelos Correios, transformando os transportes e as comunicações numa unidade de integração (Anexos 1, 2, 3 e 4).

Dada a concentração litorânea e colonial, na primeira década do século $\mathrm{XX}$, foram abertas novas linhas nesse amplo espaço. Cabe destacar nesse período algumas linhas, como: as de Estreito a Laguna, Estreito a Itajaí, Pedras Grandes a Criciúma, passando por Azambuja, Blumenau a Rodeio, mas também, subindo a Serra Geral, as linhas de Estreito a Lages, Lauro Müller a São Joaquim da Costa da Serra, e, no Planalto Serrano, Lages a Coxilha Rica, e, no Planalto Norte, Porto União da Vitória a Santa Cruz de Canoinhas. E com a expansão da colonização na direção Oeste, em 1919, foram abertas linhas de Passo Bormann (Chapecó) a Xanxerê, Passo Bormann a Herval, Herval a Campos Novos, com destaque para a linha de Passo Bormann a Mafra, interligando a região Oeste ao Planalto Norte, e Herval a Lages, passando por Campos Novos, Baguais e Cerrito em 1929, reforçando o acesso da região Oeste pelo Planalto Serrano (Anexo 2) (SANTA CATARINA, 1914; DIRETORIA-GERAL DO CORREIOS, 1920-1930; A REPÚBLICA, 1929). (Anexos 1, 2, 3 e 4). 
Tabela 2 - Número de linhas postais por sistema de condução em Santa Catarina (1923-1928)

\begin{tabular}{cccccccc}
\hline Ano & $\begin{array}{c}\text { Estrada de } \\
\text { Ferro }\end{array}$ & Cavalo & Pedestre & Fluvial & Automóvel & $\begin{array}{c}\text { Carros e } \\
\text { outros } \\
\text { veículos }\end{array}$ & Total \\
\hline 1923 & 5 & 64 & 32 & 4 & 2 & - & 107 \\
1924 & 5 & 74 & 36 & 4 & 2 & - & 121 \\
1925 & 5 & 51 & 29 & 4 & 2 & 31 & 122 \\
1926 & 5 & 51 & 29 & 4 & 2 & 31 & 122 \\
1927 & 6 & 59 & 36 & 4 & 2 & 31 & 138 \\
1928 & 6 & 61 & 38 & 4 & 4 & 34 & 147 \\
\hline
\end{tabular}

Fonte: Fonte: Relatórios da Diretoria-Geral do Correios, 1923-1928.

Na tabela acima, temos o número de linhas por sistema de condução, dos anos de 1923 a 1928. Utilizando as ferrovias, havia cinco linhas em 1923, passando para seis em 1928 (EFSPRG, EFDTC e EFSC); a cavalo, em 1923, eram 64 linhas, passando para 61 em 1928, com extensão entre 1.011 quilômetros (1923) a 823 quilômetros (1928); nas linhas pedestres (ou a pé) foram de 32 com 56 quilômetros (1923), a 38 com 151 quilômetros (1928). Nas linhas fluviais, não houve alteração, mantendo-se quatro linhas (rio Itajaí-Açu, rio Negro, rio Iguaçu e rio Uruguai) com 113 quilômetros e prolongamento para 121 quilômetros no ano de 1928. Automóveis e caminhões de pequeno porte passaram a ser utilizados nos anos de 1920, concomitantemente ao melhoramento das condições das estradas, chegando ao final do período com quatro linhas de condução por automóvel e 34 por caminhões e outros veículos terrestres, com extensão, respectivamente, de 52 quilômetros em 1923 para 402 quilômetros em 1928, e 569 quilômetros em 1925 e 612 quilômetros em 1928. Os caminhões de pequeno porte substituíram o sistema de condução de linhas a cavalo e pedestres (DIRETORIA-GERAL DO CORREIOS, 1923-1928). Em 20 de outubro de 1929, foi criada a linha de Herval a Lages, passando por Campos Novos, Baguais e Cerrito, de condução por automóvel (A REPÚBLICA, 1929). Por fim, observando o Anexo 2, percebe-se que houve um incremento de 33 linhas entre 1913 e 1915, e de 40 linhas entre 1923 e 1927, com aumento de linhas de curta e média distância a cavalo e pedestres, inclusive com a abertura de novas linhas entre municípios de uma mesma região.

Em 1927, começou a operar em Santa Catarina o serviço aéreo servido por três aviões da Syndicato Condor - subsidiária da alemã Lufthansa no Brasil - que realizava a condução de malas postais entre Alemanha, Espanha, Gâmbia, Brasil, 
Uruguai, Argentina, Chile, Peru, Bolívia e Equador. No Brasil, o Syndicato Condor cobria todas as capitais do litoral entre Natal e Porto Alegre. Em Santa Catarina, fazia escalas em São Francisco do Sul e Florianópolis; em seguida, acrescentou semanalmente as escalas em Itajaí e Laguna. No ano de 1928, mais uma companhia passou a operar em Santa Catarina, a francesa Compagnie Générale Aéropostale (CGA), que realizava viagens entre França, Espanha, Marrocos, Senegal, Brasil, Uruguai, Argentina e Chile. Em 1929, a NYRBA subsidiária da norte-americana Pan American World Airways - também começou a realizar voos entre Nova York, Rio de Janeiro e Buenos Aires, com várias escalas nas capitais brasileiras. Em 1930, foi incluída a escala no aeroporto de Florianópolis (DIRETORIA-GERAL DO CORREIOS, 1928-1930). Observando a Tabela 3, que traz o volume de malas e objetos expedidos e recebidos entre 1928 e 1930 para Santa Catarina e Brasil, percebe-se um aumento substancial nesse curto período, revelando o impacto dessa nova modalidade sobre os serviços dos correios.

Tabela 3 - Volume total expedido e recebido pelas companhias aéreas internacionais que faziam escalas em Santa Catarina (1928-1930)

\begin{tabular}{|c|c|c|c|c|c|c|c|}
\hline \multirow{2}{*}{ Ano } & \multirow{2}{*}{ Destino } & \multicolumn{3}{|c|}{ Expedida } & \multicolumn{3}{|c|}{ Recebida } \\
\hline & & Objetos & Malas & Peso & Objetos & Malas & Peso \\
\hline \multirow{3}{*}{$\begin{array}{l}\infty \\
\stackrel{\sim}{\sim}\end{array}$} & Florianópolis & 2.008 & 479 & 131.670 & 1.823 & 455 & 29.770 \\
\hline & São Francisco do & 341 & 67 & 4.492 & 487 & 87 & 8.660 \\
\hline & Brasil & 114.521 & 6.274 & 2.589 .760 & 116.359 & 6.465 & 2.320 .611 \\
\hline \multirow{3}{*}{ Әે } & Florianópolis & 13.310 & 1.112 & 322.684 & 8.608 & 914 & 253.739 \\
\hline & São Francisco do & 3.197 & 381 & 54.420 & 1.339 & 295 & 26.971 \\
\hline & Brasil & 426.413 & 13.661 & 9.982 .576 & 377.861 & 12.344 & 7.347 .529 \\
\hline \multirow{3}{*}{ ô } & Florianópolis & 31.662 & 2.984 & 652.966 & 23.070 & 2.398 & 595.612 \\
\hline & São Francisco do & 4.035 & 238 & 75.362 & 1.864 & 211 & 46.718 \\
\hline & Brasil & 798.346 & 27.326 & 15.100 .36 & 636.289 & 21.562 & 10.676 .076 \\
\hline
\end{tabular}

Fonte: Relatórios da Diretoria-Geral do Correios, 1928-1930.

Essa combinação de modalidades de transportes com as linhas postais forma as camadas geoeconômicas que permitem um maior adensamento do Estado no território, formando sistemas regionais de economia. A modernização dos meios de comunicação anda no mesmo ritmo do aperfeiçoamento dos sistemas de transportes. Exigir melhorias nos meios de comunicação implica em realizar novos 
investimentos no sistema de transportes. Com o avanço das forças produtivas e das relações de produção, o grau de exigência de modernização vai se ampliando e agregando novas camadas geoeconômicas, como telégrafos, telefonia e energia. A cada nova camada que se assenta numa região, num primeiro momento, as condições locais são reafirmadas, e, após um período de maturação, novos ritmos são impressos no processo civilizatório.

\subsection{Movimento postal e alargamento da divisão social do trabalho}

A eficiência dos serviços postais estava associada à disponibilidade de estruturas postais ágeis, como as linhas operadas por ferrovias, automóveis e aviões, além da presença nas agências de trabalhadores qualificados e de equipamentos adequados ao fluxo crescente de correspondências e encomendas. Quanto mais linhas disponíveis, maior era a possibilidade de as encomendas chegarem ao seu destino. Entregar e receber cartas, encomendas, valores e objetos fazem a razão de ser da existência dos Correios. Nessa tarefa hercúlea de chegar a todos os lugares possíveis, os serviços postais difundiram conhecimento, integraram populações e permitiram o acesso aos mais diversos tipos de bens e serviços.

Os Correios eram os responsáveis pela distribuição de jornais, revistas e outros periódicos, portanto difundiam notícias e formavam opinião que interessava tanto aos burgueses como aos trabalhadores. Nas Tabelas 4 e 5, podemos observar os jornais postados e distribuídos pelos correios em Santa Catarina. Durante o período analisado foi editada uma série de jornais de circulação municipal e estadual, alguns com vida curta e outros mais perenes. Entre os jornais de maior circulação estadual podemos destacar A República, O Dia e O Estado, que eram distribuídos pelos correios e chegavam às principias cidades catarinenses. Entre os jornais municipais que também tinham uma inserção estadual, sobretudo na capital, em Joinville destacavam-se a Gazeta de Joinville e A Notícia; em Blumenau, o BlumenauerZeitung era editado em alemão e tinha circulação nas colônias do vale do Itajaí; no Sul do estado, o maior jornal de circulação era o lagunense $\mathrm{O}$ Albor, cujos exemplares também chegavam à capital do estado; em Jaraguá do Sul, o Correio do Povo tinha inserção regional; e, no Planalto Serrano, o Correio de Lages e $\mathrm{O}$ Lageano também chegavam à capital e às principais cidades da região; no Planalto Norte, em Canoinhas, era editado O Democrata, de 
circulação regional; em São Bento do Sul, O Catharinense e o Volks Zeitung (editado em alemão e português) eram os dois maiores jornais da cidade com circulação regional; em São Francisco do Sul, o jornal A Razão tinha uma tiragem expressiva e circulava no Litoral Norte; e, por fim, no Oeste, O Chapecó e O Sertanejo, que tiveram vida curta, circulavam na região (MACHADO, MARCELINO, 2014).

Tabela 4 - Correspondências postadas na Administração de Santa Catarina (1901-1923)

\begin{tabular}{cccccc}
\hline Ano & Ofícios & Cartas & Jornais & Impressos & Bilhetes \\
\hline 1901 & 6.149 & 242.615 & 853.862 & 52.667 & 7.483 \\
1902 & 9.297 & 152.430 & 191.042 & 47.849 & 3.891 \\
1903 & 18.629 & 242.721 & 98.901 & 95.476 & 7.476 \\
1904 & 21.019 & 251.375 & 100.826 & 117.502 & 7.929 \\
1905 & 21.705 & 321.404 & 102.924 & 122.585 & 8.469 \\
1906 & 14.078 & 270.376 & 276.530 & 126.538 & 46.030 \\
1907 & 12.180 & 212.763 & 276.523 & 122.578 & 45.936 \\
1908 & 31.334 & 349.926 & 427.622 & 157.927 & 70.845 \\
1912 & 25.226 & 235.819 & 972.991 & 702.101 & 107.821 \\
1918 & 57.652 & 196.733 & 715.024 & 640.708 & 108.723 \\
1920 & 26.750 & 167.312 & 23.225 & 62.452 & 38.419 \\
1921 & 95.288 & 562.326 & 42.112 & 149.005 & 76.398 \\
1922 & 96.415 & - & - & - & - \\
1923 & 69.405 & - & 414.736 & 399.414 & 47.070 \\
\hline
\end{tabular}

Fonte: Relatórios da Diretoria-Geral do Correios, 1901-1924.

Os documentos oficiais entre órgãos públicos das três esferas de governo (União, estados e municípios) também eram entregues pelos Correios. Portanto, os Correios soldavam as relações institucionais do Estado por meio da circulação de documentos oficiais e racionalizam os processos burocráticos. Mesmo com a difusão dos telégrafos e o início da formação das linhas telefônicas no final dos anos de 1920, a circulação de documentos oficiais entregue pelos Correios manteve-se em plena atividade. A circulação de ofícios entregues pelos correios se dava com maior intensidade entre as superintendências e conselhos municipais com o Executivo e o Legislativo estadual. O alargamento das funções do Estado e seu adensamento nas diversas cidades catarinenses, por meio da instalação de órgãos públicos, ampliaram a comunicação entre a capital e o interior com a difusão de correspondências oficiais. Essa comunicação ocorria entre os cartórios 
de registro civil e de imóveis e cartórios de protestos e notas que estavam instalados nas sedes municipais. Destaca-se também a comunicação entre a Diretoria de Instrução Pública e as diversas escolas da rede estadual de educação. Outro importante órgão estadual era a Secretaria de Estado da Fazenda (Tesouro Estadual) e as coletorias das rendas municipais de arrecadação tributária e as alfândegas. No âmbito da segurança pública, a comunicação era feita entre as delegacias de polícia, os quartéis e as juntas militares com a Secretaria do Interior e Justiça e o Ministério da Guerra. Os relatos dos engenheiros que executavam as obras públicas no interior do estado à Secretaria de Viação e Obras Públicas eram feitos por meio de cartas entregues pelos estafetas. Por fim, a comunicação entre a Justiça Eleitoral de Santa Catarina e os alistamentos eleitorais dos municípios realizados durante as eleições era amparada pelos serviços postais dos correios.

Tabela 5 - Correspondências distribuídas pela Administração de Santa Catarina (1901-1924)

\begin{tabular}{cccccc}
\hline Ano & Ofícios & Cartas & Jornais & Impressos & Bilhetes \\
\hline 1901 & 5.351 & 259.053 & 647.796 & 99.932 & 3.768 \\
1902 & 7.079 & 238.469 & 220.348 & 82.945 & 1.325 \\
1904 & 14.044 & 303.036 & 371.624 & 232.096 & 6.923 \\
1905 & 15.599 & 313.889 & 391.709 & 307.396 & 8.737 \\
1906 & 17.803 & 378.275 & 440.529 & 311.141 & 11.889 \\
1907 & 12.546 & 376.404 & 414.313 & 301.645 & 58.549 \\
1908 & 21.255 & 435.506 & 544.965 & 411.367 & 154.072 \\
1912 & 27.769 & 618.271 & 465.420 & 889.545 & 152.806 \\
1918 & 51.231 & 318.168 & 996.994 & 770.335 & 50.037 \\
1920 & 39.828 & - & - & 927.766 & 121.094 \\
1921 & 63.515 & 434.138 & 588.074 & 561.364 & 50.255 \\
1922 & 80.767 & 745.063 & 720.415 & - & 88.141 \\
1923 & 181.677 & - & 498.956 & 886.087 & 182.124 \\
1924 & 66.839 & - & & 945.992 & 73.867 \\
\hline
\end{tabular}

Fonte: Relatórios da Diretoria-Geral do Correios, 1901-1924.

Também era de responsabilidade dos Correios fazer a entrega de encomendas e objetos comercializados via postal entre comerciantes, industriais e consumidores, portanto, promovia a expansão do comércio e mercantilizava as relações sociais. Com o lançamento dos bilhetes simples, duplo e industrial privado, dispensando o envelope, ocorreu um barateamento da emissão de correspondências, promovendo uma expressiva disseminação desse novo serviço 
(DIRETORIA-GERAL DO CORREIOS, 1901-1930). Por fim, as tradicionais cartas que chegavam às casas da população em geral eram entregues pelos carteiros, portanto, os Correios aproximavam as pessoas numa rede de assuntos cotidianos de saudades, alegrias e tristezas

Outro serviço importante realizado pelos Correios era o pagamento e recebimento de vales postais em nível nacional e internacional. Nas comunidades mais distantes dos centros urbanos, os Correios constituíam-se num agente monetizador da economia local. Emitido na forma de um bilhete, o destinatário tinha o direito de sacar na agência o valor expresso no bilhete. $\mathrm{O}$ transporte dos vales postais pelos estafetas e o depósito dos valores nas agências dos Correios revelam o grau de importância que essa instituição assumia no interior do país. Antes da proliferação dos bancos comerciais, em muitos casos, os Correios assumiam a função de distribuidor do papel-moeda. Observando a movimentação total dos vales postais em Santa Catarina, percebe-se que o valor movimentado pela Administração e pelas agências no interior era muito expressivo. Para termos a dimensão desse movimento, a Tabela 6 traz o total dos vales postais (emitidos e recebidos) comparando com as exportações de erva-mate, um dos principais produtos exportados por Santa Catarina. Fazendo uma média simples por década, entre 1904 e 1929, a movimentação total dos vales postais representava 29,40\% do total das exportações de erva-mate. Na década seguinte, com base nos anos de 1911, 1912, 1918 e 1919, a média elevou-se para 30,65\%, ou seja, um valor muito expressivo, haja vista que foi a década do auge da expansão do complexo ervateiro catarinense. Por fim, na década de 1920, houve uma queda, passando para 13,73\%, mesmo assim, os valores absolutos do total de vales postais aumentaram 2,5 vezes no período. 
Tabela 6 - Movimentação financeira dos vales postais e a participação sobre o total exportado da erva-mate (1904-1929)

\begin{tabular}{cccccccc}
\hline \multirow{2}{*}{ Ano } & \multicolumn{2}{c}{ Administração } & \multicolumn{2}{c}{ Agências } & Total & $\begin{array}{c}\text { Exportaçoes } \\
\text { Erva-mate }\end{array}$ & $\begin{array}{c}\text { Exp. } \\
\text { Erva/Vale } \\
\text { postal (\%) }\end{array}$ \\
\hline 1904 & $315: 621 \$ 244$ & $65: 662 \$ 788$ & $37: 900 \$ 170$ & & 419.184 & $1.378: 030 \$ 0$ & 30,42 \\
1905 & $384: 053 \$ 765$ & $68: 103 \$ 103$ & $40: 675 \$ 384$ & & 492.832 & $1.338: 722 \$ 0$ & 36,81 \\
1906 & $242: 139 \$ 897$ & $78: 776 \$ 144$ & $62: 068 \$ 705$ & & 382.984 & $1.467: 044 \$ 0$ & 26,11 \\
1907 & $166: 050 \$ 889$ & $103: 102 \$ 030$ & $46: 769 \$ 392$ & & 315.922 & $1.444: 401 \$ 0$ & 21,87 \\
1908 & $282: 992 \$ 204$ & $107: 857 \$ 835$ & $87: 065 \$ 180$ & & 477.915 & $1.479: 030 \$ 0$ & 32,31 \\
1909 & $298: 041 \$ 139$ & $155: 102 \$ 887$ & & & 453.144 & $1.567: 960 \$ 0$ & 28,90 \\
1911 & $294: 018 \$ 225$ & $171: 776 \$ 106$ & & & 465.794 & $1.287: 784 \$ 0$ & 36,17 \\
1912 & $292: 711 \$ 347$ & $173: 929 \$ 225$ & $132: 908 \$ 20$ & $64: 013 \$ 281$ & 663.562 & $1.164: 589 \$ 0$ & 56,98 \\
1918 & $173: 518 \$ 100$ & $186: 175 \$ 000$ & $298: 558 \$ 00$ & $119: 105 \$ 100$ & 777.356 & $3.645: 876 \$ 0$ & 21,32 \\
1919 & $156: 395 \$ 400$ & $200: 409 \$ 800$ & $299: 705 \$ 70$ & $111: 046 \$ 500$ & 767.557 & $9.420: 967 \$ 0$ & 8,15 \\
1920 & $167: 741 \$ 400$ & $338: 651 \$ 400$ & $182: 750 \$ 60$ & $97: 337 \$ 300$ & 786.480 & $4.978: 005 \$ 0$ & 15,80 \\
1921 & $181: 548 \$ 600$ & $228: 943 \$ 500$ & $378: 862 \$ 40$ & $126: 178 \$ 100$ & 915.532 & $6.860: 339 \$ 0$ & 13,35 \\
1922 & $162: 221 \$ 800$ & $195: 948 \$ 500$ & $328: 022 \$ 00$ & $135: 452 \$ 700$ & 821.645 & $7.047: 689 \$ 0$ & 11,66 \\
1923 & $188: 866 \$ 700$ & $230: 826 \$ 600$ & $113: 322 \$ 80$ & $146: 171 \$ 300$ & 679.187 & $7.553: 696 \$ 0$ & 8,99 \\
1924 & $203: 065 \$ 100$ & $238: 318 \$ 500$ & $175: 954 \$ 10$ & $180: 830 \$ 300$ & 798.168 & $6.471: 063 \$ 0$ & 12,33 \\
1925 & $219: 917 \$ 400$ & $268: 703 \$ 400$ & $543: 314 \$ 90$ & $207: 479 \$ 400$ & 1.239 .41 & $7.291: 178 \$ 0$ & 17,00 \\
1926 & $208: 134 \$ 500$ & $261: 587 \$ 800$ & $491: 134 \$ 50$ & $189: 958 \$ 800$ & 1.150 .81 & $7.143: 910 \$ 0$ & 16,11 \\
1927 & $227: 716 \$ 700$ & $306: 917 \$ 000$ & $640: 763 \$ 50$ & $227: 504 \$ 300$ & 1.402 .90 & $8.184: 258 \$ 0$ & 17,14 \\
1928 & $299: 985 \$ 400$ & $322: 056 \$ 000$ & $883: 283 \$ 80$ & $307: 126 \$ 200$ & 1.812 .45 & $17.379: 300 \$$ & 10,43 \\
1929 & $271: 011 \$ 100$ & $291: 130 \$ 000$ & $1.007: 075 \$$ & $376: 359 \$ 300$ & 1.945 .57 & $13.456: 788 \$$ & 14,46 \\
\hline
\end{tabular}

Fonte: Relatórios da Diretoria-Geral do Correios, 1904-1930.

Novos produtos e serviços iam sendo criados pelos Correios para atender às demandas sociais e para executar serviços de distribuição de encomendas que ainda não eram realizados pelos agentes privados. Foram estabelecidos serviços de entrega expressa, vales postais nacionais e internacionais, colis postaux (encomenda postal), caixa de assinantes, coleta de caixas urbanas, entrega domiciliar, entrega de jornais e revistas, cartas, bilhetes, permutação de caixas e cartas com e sem valores declarados. O uso de colis postaux internacional era significativo nas regiões onde havia grande contingente de imigrantes, os quais ainda mantinham contato com parentes no seu país de origem - como era o caso das agências de correios instaladas nas principias colônias catarinenses. Outros serviços relevantes eram a entrega rural e a correspondência expressa, ambas chegavam aos pontos mais distantes dos centros urbanos e de difícil acesso. Tais serviços eram considerados vitais para os Correios se fazerem presente em todo o território nacional (DIRETORIA-GERAL DO CORREIOS, 1923-1930). 
Tabela 7 - Colis postaux expedido e recebido pela Administração dos Correios de Santa Catarina (1923-1930)

\begin{tabular}{ccc}
\hline Ano & Expedido & Recebido \\
\hline 1923 & 84 & 2.361 \\
1924 & 152 & 424 \\
1925 & 90 & 686 \\
1926 & 89 & 1.068 \\
1927 & 63 & 1.081 \\
1928 & 8 & 421 \\
1929 & 1.641 & 262 \\
1930 & 1.840 & 233 \\
\hline
\end{tabular}

Fonte: Relatórios da Diretoria-Geral do Correios, 1923-1930.

Quando analisamos a evolução dos dados do movimento postal em Santa Catarina no período de 1900 a 1930, com destaque para objetos, malas, ofícios, cartas, jornais, impressos, bilhetes, vales postais e colis postaux, percebe-se que há uma trajetória contínua de crescimento em todos os itens, com breves momentos de retração ou de expansão acelerada. $\mathrm{Na}$ verdade, há uma relação muito estreita entre o alargamento da sociedade e das condições materiais da economia catarinense com a expansão do movimento postal. Fundada na pequena produção mercantil e na extração mineral e vegetal, o padrão de crescimento da economia catarinense nesse período ainda assumia característica de um mercado interno em formação. Nos sistemas regionais de economia baseados em atividades econômicas específicas - erva-mate, madeira, carvão, alimentos e têxtil -, ao mesmo tempo em que havia um crescimento das atividades produtivas, paralelamente surgiam novas demandas por transportes e comunicação. Portanto, correios, produção e transportes formam uma unidade na diversidade.

Outro serviço ofertado pelos Correios eram as caixas de assinatura (caixa postal), as quais permitiam maior comodidade aos assinantes na busca de suas correspondências. Inicialmente, a oferta desse serviço estava disponível apenas na capital, mas, com a ampliação das agências, em seguida, chegou às maiores cidades do interior. Como era um serviço muito caro, no início - década de 1910 - era pouco utilizado, mas, com a ampliação da oferta, o preço por assinatura caiu e o serviço se popularizou. Como pode ser visualizado na tabela abaixo, em 1923 já se encontravam caixas para assinatura, além da capital, em Joinville, Laguna e 
Itajaí. Em 1927, também em Blumenau, São Francisco e, no ano de 1928, em Porto União. Havia também o serviço de coleta urbana realizado por meio das caixas disponibilizadas nas cidades, onde eram depositadas as cartas e, no final do dia, o carteiro fazia a coleta para serem expedidas na agência. Inicialmente, esse serviço era disponibilizado apenas em Florianópolis, mas na década de 1920 também chegou ao interior. Em 1924, eram três caixas de coleta em Florianópolis, três em Joinville, duas em Blumenau e uma em Laguna e Itajaí. Em 1928, foi acrescida uma caixa em Florianópolis e Blumenau e instalada uma em São Francisco do Sul (DIRETORIA-GERAL DOS CORREIOS, 1900-1930)

Tabela 8 - Caixas de assinatura e de coleta urbana dos Correios em Santa Catarina (1900-1930)

\begin{tabular}{|c|c|c|c|}
\hline \multirow{2}{*}{ Ano } & \multicolumn{2}{|c|}{ Caixas de assinatura } & \multirow{2}{*}{$\begin{array}{c}\text { Caixas de } \\
\text { coleta urbana }\end{array}$} \\
\hline & Existente & Ocupadas & \\
\hline 1900 & 96 & 20 & 7 \\
\hline 1901 & 96 & 11 & \\
\hline 1902 & 96 & 9 & \\
\hline 1904 & 96 & 8 & \\
\hline 1905 & 96 & 8 & 5 \\
\hline 1906 & 96 & 8 & 5 \\
\hline 1907 & 96 & 14 & 5 \\
\hline 1908 & 96 & 16 & 5 \\
\hline 1909 & 96 & 16 & 6 \\
\hline 1912 & 96 & & 4 \\
\hline 1918 & 140 & 110 & 2 \\
\hline 1920 & 141 & 141 & \\
\hline 1921 & 142 & 142 & 1 \\
\hline 1922 & 142 & 142 & 1 \\
\hline 1923 & 468 & & 13 \\
\hline 1924 & 468 & & 10 \\
\hline 1925 & 468 & & 10 \\
\hline 1926 & & & 11 \\
\hline 1927 & 531 & 359 & 11 \\
\hline 1928 & 591 & & 13 \\
\hline 1929 & 910 & & \\
\hline 1930 & 1.006 & 590 & \\
\hline
\end{tabular}

Na primeira década do século XX, a distribuição domiciliar feita por carteiros urbanos ainda era realizada diariamente apenas em Florianópolis, com 
até quatro saídas diárias da agência central para os bairros. No início dos anos 1920, esse serviço se estendeu até o interior e às cidades de Joinville, São Francisco do Sul, Itajaí, Indaial, Lages, Mafra, Tijucas, Tubarão, Brusque, São José e São Bento do Sul passaram a ter suas correspondências e encomendas entregues pelos carteiros (ALMANAK LAEMMERT, 1901-1926).

\subsection{Movimento financeiro: persistência de déficit versus compromisso socioeconômico}

Analisando a trajetória das receitas e despesas da Administração dos Correios de Santa Catarina de 1900 a 1930, temos um acúmulo contínuo de déficits e o aumento no volume da movimentação postal. O Tesouro Nacional também financiava os insistentes déficits gerados pelos correios e pelos telégrafos, além de conceder subvenções às companhias de navegação e garantia de juros às companhias ferroviárias. Manter em funcionamento as estruturas de transporte e comunicações implicava em recorrer a subsídios e déficits, sob pena de paralisar os fluxos internos no país caso houvesse cortes abruptos no orçamento.

O déficit financeiro dos Correios brasileiro não era uma anomalia nem entendido como fato isolado dentro da União Postal Universal, mas como recorrente entre as diversas administrações postais em todos os continentes. Em boa medida, segundo os administradores das agências centrais, a persistência dos déficits financeiros decorria, principalmente, em função das isenções de taxas às correspondências oficiais que circulavam na burocracia estatal (DIRETORIAGERAL DOS CORREIOS, 1900-1930).

No entanto, do ponto de vista da economia nacional, os constantes déficits dos Correios, segundo seus diretores, eram compensados pela maior abrangência de seus serviços para a população em geral e pela sua vital importância para a sociedade brasileira. A despeito dos resultados financeiros negativos, era rotineiro os agentes postais enviarem à Administração, e os diretores enviarem ao Ministério, pedidos para suprirem a necessidade de expansão e modernização dos serviços, sempre alegando a necessidade de alcançar o vasto território nacional. Os pedidos para abertura de novas agências ou linhas eram encaminhados para a Administração estadual dos Correios, localizada em Florianópolis, que por sua vez analisava o pedido e o reenviava à Diretoria-Geral dos Correios, localizada no Rio de Janeiro. Na capital federal, a Diretoria hierarquizava as solicitações recebidas 
das administrações estaduais e, após uma análise econômica e social, liberava os recursos solicitados ou incluía no orçamento do próximo ano (DIRETORIAGERAL DOS CORREIOS, 1900-1930).

Era comum as receitas crescerem após o estabelecimento de novas agências e o aumento na oferta de portfólio de produtos e serviços, o que permitia sustentar uma taxa de crescimento menor para o déficit, porém não "exorcizava o fantasma" dos resultados negativos. Os serviços postais não eram tratados pelos seus resultados financeiros, mas pela sua inserção social, como uma ferramenta de cooperação entre distintos agentes econômicos, que, por sua vez, impulsionavam as atividades econômicas, fixavam população e criavam bases para o estabelecimento de outros serviços abertos pelas linhas postais.

No ano de 1900, foi registrado um déficit financeiro de 28:851\$986, que representava 50,46\% do valor total da receita, de 57:174\$769. No final da década, em 1909, o déficit saltou para 82:550\$164, porém reduziu a sua relação com a receita, 17,59\%, de 100:179\$475. Na década seguinte, a trajetória do déficit seguiu com momento de crescimento acelerado, como em 1912, que chegou a 294:642\$526, representando $199,62 \%$ acima da receita. O lento aumento da receita era desproporcional ao aumento das despesas. Em 1910, a receita foi de 83:343\$740, e as despesas, 270:951\$214; e, no final da década, em 1919, 162:721\$520 e 340:726\$560, respectivamente. Nos anos de 1920, houve um aumento mais considerável da receita, passando de 224:712\$794 em 1920 para 1.064:362\$849 em 1929, porém as despesas seguiram no mesmo ritmo de crescimento, passando de 486:127\$631 em 1920, para 1.414:535\$098 em 1928 (Anexo 3).

Cabe ressaltar que, dos 25 anos disponíveis no Anexo 3, 11 anos registraram um percentual abaixo de $100,0 \%$ do déficit em relação à receita, enquanto 14 ultrapassaram os 100,0\%, com destaque para os anos de 1910 e 1912 que registram $225,10 \%$ e 299,62\%, respectivamente. As maiores variações da despesa e da receita foram, respectivamente, nos anos de 1926-1927 e 1927-1928, de 73,84\% e $75,92 \%$. Num comparativo por década, os anos entre 1910 e 1919, as receitas variaram positivamente em média anual de 8,20\% nas receitas e as despesas em $5,74 \%$. Na década seguinte, houve um aumento considerável na variação, passando as receitas para 22,25\%, e as despesas para 19,73\%. Mesmo assim, os saldos da variação relativa na receita desse período não foram suficientes para cobrir os 
crescentes déficits, tendo as despesas aumentado em até 2,25 vezes em relação à receita.

Numa análise geral da movimentação financeira, percebem-se dois momentos diferentes. O primeiro cobre até o final da década de 1910, quando predominava a litoralização e interiorização para as colônias e Planalto Serrano dos serviços postais, quando o crescimento da receita foi mais lento. O segundo tem início com a disseminação acelerada em direção ao Planalto Norte e o Grande Oeste, quando aumentaram os gastos da Administração dos Correios de Santa Catarina com a abertura de novas agências e linhas postais no território em litígio, cujo resultado é o aumento nas receitas. Contudo, esse aumento era incapaz de cobrir as despesas. Isso nos permite concluir que quanto maiores eram os investimentos da Administração nas áreas de expansão econômica, maiores eram suas receitas.

\subsection{Estafetas, carteiros e agentes na expansão dos serviços postais}

As profissões de carteiro e estafeta nascem no mesmo instante em que surgem os serviços postais. $\mathrm{O}$ ato de levar uma correspondência de um lugar a outro só pode ser concretizado pela intermediação de um carteiro ou estafeta. No Brasil, o dia do carteiro é comemorado em 25 de janeiro em alusão à nomeação pela Coroa do alferes João Cavalheiro Cardozo para a função de Correio-Mor do Mar e Correio-Mor da Terra em 1663 (ROSÁRIO, 1993). Nos documentos históricos dos Correios do século XIX, mesmo aparecendo com sinônimos, as funções dos estafetas e carteiros eram diferentes. Os estafetas - que mais tarde passaram a se chamar "condutores de malas" - realizavam a entrega de correspondências e encomendas de uma agência a outra utilizando como meios de locomoção cavalo, barco, trem ou mesmo a pé. Os carteiros realizavam as entregas no perímetro urbano, nos domicílios, repartições públicas, empresas e outras entidades. Os estafetas eram os que enfrentavam as maiores dificuldades de locomoção, cruzando rios, montanhas, matas fechadas e lugares inóspitos. Para lidar com as adversidades quando se embrenhavam nas matas, eles deveriam andar armados para se proteger de animais ferozes, bandoleiros e "índios hostis". Em razão dos riscos que enfrentavam, a permanência dos estafetas na função era muito instável e curta, o que obrigava a Administração dos Correios a realizar constantes chamadas públicas para contratar os serviços de estafetas (DIRETORIA-GERAL 
DOS CORREIOS, 1900-1930). Essas dificuldades também estavam relacionadas às condições das estradas que cortavam o território brasileiro, as quais, em sua ampla maioria, eram precárias e recebiam pouca manutenção.

A prática de realizar chamadas públicas fez dos Correios brasileiro uma das primeiras instituições públicas a realizar concursos para a contratação de agentes postais e carteiros regulamentados pelo Decreto n. ${ }^{\circ}$ 9.912, de 26 de março de 1888 (BRASIL, 1889). O primeiro concurso público para os Correios, em Santa Catarina, ocorreu em 14 de janeiro de 1895, cujo edital foi publicado no jornal A República, em 11 de dezembro de 1894. Para os cargos de oficial, praticante e carteiro, o edital fazia as seguintes exigências:

$\checkmark$ Para os lugares de $2^{\circ}$ oficial, serão admitidos os amanuenses e, na falta destes, os praticantes. Os pretendentes devem dominar a legislação postal interna e da convenção postal universal. Também serão realizadas provas práticas sobre a execução de serviços da seção em que o candidato tiver exercício.

$\checkmark$ Para os lugares de praticante, os candidatos deverão ter mais de 21 e menos de 30 anos de idade, exceto se já tiverem exercício nos Correios. Deverá gozar de boa saúde e estar vacinado, ter bom procedimento, conhecer a língua portuguesa e francesa, geografia geral e do Brasil, aritmética e teoria das proporções matemáticas. Também deverão ter algum conhecimento em desenho linear, escrituração mercantil e a língua inglesa e alemã.

$\checkmark$ Para os lugares de carteiro, os candidatos deverão ter mais de 21 e menos de 30 anos de idade, exceto se já tiverem exercício nos Correios. Deverão gozar de boa saúde e estar vacinados; ter bom procedimento, saber ler e escrever corretamente e conhecer as quatro operações fundamentais da aritmética (A REPÚBLICA, 1894).

Por determinação da Diretoria-Geral dos Correios, nos anos seguintes, em todos os estados da Federação, adotou-se o concurso. Na Tabela 9, podemos acompanhar o número de concursos realizados em Santa Catarina, a quantidade de candidatos que se inscreveram e o total de classificados entre 1901 e 1927. Percebe-se que a prática de concurso nos Correios é comum nesse período, variando de um a sete concursos por ano. Em 1910, houve apenas um concurso com dois inscritos para duas vagas, mas, em 1907, foram dois concursos com 41 
inscritos e 25 selecionados, repetindo essa proporção em 1922, quando, dos 53 inscritos, 13 foram selecionados e, em 1924, dos 39, apenas 18 foram aprovados. Contudo, houve momentos em que quase a totalidade de inscritos foi selecionada, como no ano de 1909, dos 78 inscritos, 74 foram classificados. No período analisado e com base nos dados disponíveis, ocorreram em Santa Catarina 35 concursos, com 323 candidatos inscritos e 234 classificados. A realização desse concurso revela o quanto os Correios brasileiro, há mais de um século, tem critérios rígidos e transparentes na contratação de seus trabalhadores e trabalhadoras.

\section{Tabela 9 - Concursos realizados pela Administração dos Correios de Santa Catarina (1901-1927)}

\begin{tabular}{cccc}
\hline Ano & $\begin{array}{c}\text { Número de } \\
\text { concursos }\end{array}$ & Candidatos & Classificados \\
\hline 1901 & 1 & 2 & 2 \\
1902 & 2 & 14 & 13 \\
1905 & 2 & 39 & 38 \\
1906 & 2 & 8 & 5 \\
1907 & 2 & 41 & 25 \\
1909 & 6 & 78 & 74 \\
1918 & 1 & 5 & 5 \\
1920 & 2 & & \\
1921 & 7 & 53 & 13 \\
1922 & 2 & 39 & 18 \\
1924 & 2 & 7 & 7 \\
1925 & 2 & 37 & 34 \\
1927 & 4 & 323 & 234 \\
Total & 35 & & \\
\hline Fon & 2 & & \\
\hline
\end{tabular}

Fonte: Relatórios da Diretoria-Geral do Correios, 1901-1927.

O fato de saber ler e escrever, conhecer aritmética, falar outra língua, ter noções de geografia e história, entender de escrituração mercantil e dominar a legislação postal nacional e universal fazia dos agentes postais, dispersos nas mais diversas cidades e localidades do interior do país, uma autoridade respeitada pela população em geral. Ao lado dos prefeitos, juízes, delegados e padres, os agentes postais também ocupavam lugar de destaque e faziam parte da elite local que decidia sobre o futuro da comunidade.

Com relação ao quadro geral de trabalhadores nos Correios catarinense, podemos dividi-lo em três seções. A primeira traz os trabalhadores que atuavam 
na Administração localizada em Florianópolis (que inclui os carteiros da cidade); a segunda seção engloba todos os agentes postais, estafetas e carteiros que trabalhavam no interior; e a terceira seção é composta pelos condutores das malas postais. Na Tabela 10, podemos acompanhar a trajetória da evolução do número de trabalhadores em Santa Catarina entre 1901 e 1930, divididos por seção, e a soma total. Percebe-se certa estabilidade no número de trabalhadores na primeira década do século e um aumento significativo nos anos de 1920. Esse movimento de expansão no número de agentes, carteiros e oficiais tem a ver com a disseminação acelerada e o alargamento das funções dos correios diante da ampliação da divisão social do trabalho que estava em marcha na economia catarinense. Também deve ser levada em consideração a aprovação da Lei n. ${ }^{\circ}$ 4.273, de 1 de fevereiro de 1921, que reorganizou os serviços dos Correios e ampliou de forma substancial o quadro de funcionários nas administrações e agências estaduais (BRASIL, 1921). Somente para Santa Catarina foi autorizada a contração de mais 18 carteiros e 52 trabalhadores para Administração em Florianópolis.

Comparando o total de classificados pelos concursos com o total anual no número de trabalhadores nos Correios catarinense, percebe-se que há um desencontro, o que nos leva a inferir que boa parte dos admitidos anualmente era para funções de carteiros, estafetas e condutores de malas. Para cada agência no interior, havia apenas um agente postal, e a sua indicação poderia ser feita pela própria Administração, que deslocava um funcionário para essa função. Pós-1918, com o movimento de disseminação acelerada para o Planalto Norte e Grande Oeste, houve um aumento mais expressivo no número de trabalhadores, passando de 139 em 1920 para 254 em 1928. 
Tabela 10 - Trabalhadores dos Correios em Santa Catarina (1901-1930)

\begin{tabular}{ccccc}
\hline Ano & $\begin{array}{c}\text { Administração } \\
\text { em Florianópolis } \\
\text { (inclui carteiros) } \\
\text { (A) }\end{array}$ & $\begin{array}{c}\text { Agências no } \\
\text { interior (Agentes, } \\
\text { carteiros e } \\
\text { estafetas) (B) }\end{array}$ & $\begin{array}{c}\text { Condutores } \\
\text { (C) }\end{array}$ & $\begin{array}{c}\text { Administração, } \\
\text { agências, } \\
\text { condutores e } \\
\text { outros (A+B+C) }\end{array}$ \\
\hline 1901 & 12 & & & \\
1902 & 13 & 44 & & 57 \\
1903 & 13 & 43 & & 56 \\
1904 & 13 & 43 & & 65 \\
1905 & 16 & 49 & & 65 \\
1906 & 16 & 49 & & 65 \\
1908 & 16 & 49 & & 66 \\
1909 & 16 & 50 & 66 & 117 \\
1910 & 29 & 69 & 69 & 139 \\
1911 & 48 & 69 & 69 & 166 \\
1920 & & & & 169 \\
1921 & 35 & 65 & 131 & 171 \\
1922 & 35 & 65 & 132 & 176 \\
1923 & & & 132 & 182 \\
1924 & & 73 & 148 & 185 \\
1925 & 77 & & 157 & 225 \\
1926 & & & 158 & 254 \\
1927 & & & &
\end{tabular}

Fonte: Relatórios da Diretoria-Geral do Correios, 1901-1930.

Em cada agência, trabalhava um agente postal, que recebia as malas conduzidas pelos estafetas, em seguida organizava as correspondências, encomendas, valores e outros para serem distribuídos. Era função da população interessada ir até a agência buscar suas correspondências ou encomendas. Havia a presença dos carteiros urbanos apenas na capital e nas maiores cidades do interior. Em 1902, havia três carteiros em Florianópolis, que atendiam a população urbana, mas não chegavam até as comunidades pesqueiras no norte e sul da Ilha de Santa Catarina. No ano de 1922, já eram 13 carteiros em Florianópolis. Nesse mesmo ano, em Blumenau, havia um carteiro para toda a cidade; em Itajaí, dois; em Joinville, dois; e, em Tijucas, dois carteiros. Aumentou também a disponibilidade de estafetas para as agências no interior que faziam linhas postais entre municípios. Blumenau contava com um estafeta; havia um estafeta na agência de Brusque; um em Camboriú; dois em Campos Novos; dois em Canoinhas; três em Curitibanos; 
quatro em Itajaí; um em Nova Trento; dois em São Bento do Sul; quatro em São Francisco do Sul; e um em Urussanga (ALMANAK LAEMMERT, 1901-1927).

\section{Considerações finais}

No Brasil, do início do século XX até 1930, a ausência de formas avançadas de organização capitalista retardou o desenvolvimento de uma economia mais organizada quando comparado com as economias centrais. Contudo, esses entraves não impediram que o país construísse um sistema nacional de economia. O mesmo podemos pensar em relação a Santa Catarina na comparação com outros estados brasileiros mais avançados. O ritmo lento de acumulação da economia catarinense não foi um entrave que impediu avanços materiais consideráveis da sua estrutura produtiva. Podemos afirmar que, durante todo o século XIX e início do XX, foi se formando um mercado interno e um sistema regional de economia, composto de camadas geoeconômicas que adensou o Estado no território catarinense.

A atuação dos Correios nas mais diversas vilas e cidades desse vasto território significa a presença do Estado na vida cotidiana das pessoas. A implantação dos serviços postais em comunidades que até então não eram servidas pelos Correios promove dois movimentos complementares. A primeira reação à chegada dos Correios é de reafirmar e reproduzir as condições postas nessa comunidade. O serviço postal se adapta ao ritmo local, e poucas mudanças são anunciadas, mantendo-se as formas pretéritas de organização econômica e social. Num segundo momento, com o adensamento das suas funções e o alastramento dos seus resultados, os Correios metamorfoseiam-se numa instituição promotora de mudanças sociais e de integração econômica. O seu amadurecimento, combinado com outras disposições materiais, contribui na alteração do padrão de acumulação e possibilita o surgimento e a consolidação de novas unidades produtivas. O mesmo podemos pensar em relação aos transportes, ao sistema de geração, transmissão e distribuição de energia e aos demais meios de comunicação, que assumem o caráter central no processo de circulação da produção global capitalista dentro do sistema nacional de economia.

Podemos dividir as permanências e mudanças dos serviços postais em Santa Catarina entre 1900 e 1930 em dois movimentos. O primeiro vai do começo do século e se estende até 1918, quando houve uma concentração litorânea e colonial 
reforçando a abertura de agências dos Correios e de linhas postais nas cidades e vilas nas áreas mais povoadas do estado. O segundo ocorreu pós-1918 com a definição do território em litígio para a jurisdição de Santa Catarina após a Guerra do Contestado e a assinatura do Acordo de Limites, caracterizando-se com o início de uma disseminação acelerada para o território do Planalto Norte e Grande Oeste.

Os Correios se constituíram como um dos principais elementos unificadores da territorialidade e do sistema nacional de economia. Dentro do processo civilizatório, a difusão de informações e do conhecimento, promovida pelos Correios - que aproximou pessoas, instituições e nações - catalisou a sociabilidade moderna. Não apenas no passado distante, mas no presente - por exemplo, toda a logística de entregas das Olimpíadas de 2016 no Rio de Janeiro ficou a cargo dos Correios - os serviços dos Correios são fundamentais para a consolidação de um projeto nacional de desenvolvimento.

\section{Referências}

A REPÚBLICA, 08/05/1919

A REPÚBLICA, 11/12/1894.

A REPÚBLICA, 12/09/1929.

A REPÚBLICA, 20/12/1918

A REPÚBLICA, 21/01/1920

A REPÚBLICA, 21/12/1926

A REPÚBLICA, 25/07/1923.

A REPÚBLICA, 30/03/1927.

ALMANAK LAEMMERT. Administrativo, agrícola, profissional, mercantil e industrial dos Estados Unidos do Brasil. $65^{\circ}$ ano. Rio de Janeiro: Adriano Maury \& C., 1908.

ALMANAK LAEMMERT. Administrativo, agricola, profissional, mercantil $e$ industrial dos Estados Unidos do Brasil, para 1911-1912. $68^{\circ}$ ano. Rio de Janeiro: Tipografia Almanak Laemmert, 1911. 
ALMANAK LAEMMERT. Administrativo, agrícola, profissional, mercantil e industrial da República dos Estados Unidos do Brasil, para 1921-1922. 77º-78 ano, v. 4(Estados do Sul). Rio de Janeiro: Tipografia Almanak Laemmert, 1921.

ALMANAK LAEMMERT. Administrativo, agrícola, profissional, mercantil e industrial da Capital Federal e dos Estados Unidos do Brasil, para 1924. 80 ano, v. 4(Estados do Sul). Rio de Janeiro: Tipografia Almanak Laemmert, 1924.

ALMANAK LAEMMERT. Administrativo, agrícola, profissional, mercantil e industrial da Capital Federal e dos Estados Unidos do Brasil, para 1925. 81 ${ }^{\circ}$ ano, v. 4(Estados do Sul). Rio de Janeiro: Tipografia Almanak Laemmert, 1925.

ALMANAK LAEMMERT. Administrativo, agrícola, profissional, mercantil $e$ industrial da Capital Federal e dos Estados Unidos do Brasil, para 1927.83ano, v. 4(Estados do Sul). Rio de Janeiro: Tipografia Almanak Laemmert, 1927.

ALMANAK LAEMMERT. Administrativo, mercantil e industrial do Rio de Janeiro, por Arthur Sauer. 58 ano. Rio de Janeiro: Companhia Tipográfica do Brasil, 1901.

ALMANAK LAEMMERT. Administrativo, mercantil e industrial do Rio de Janeiro, por Arthur Sauer. $60^{\circ}$ ano. Rio de Janeiro: Companhia Tipográfica do Brasil, 1903.

ALMANAK LAEMMERT. Administrativo, mercantil e industrial do Rio de Janeiro, por Arthur Sauer. $61^{\circ}$ ano. Rio de Janeiro: Companhia Tipográfica do Brasil, 1904.

ALMANAK LAEMMERT. Administrativo, mercantil e industrial do Rio de Janeiro, por Arthur Sauer. $63^{\circ}$ ano. Rio de Janeiro: Companhia Tipográfica do Brasil, 1906.

BANDEIRA, J. J. P. Notícia da descoberta do Campo de Palmas. Revista do Instituto Histórico e Geográfico Brasileiro. Rio de Janeiro, n. 4, 1851.

BRASIL. Decreto de 5 de março de 1829. Coleção das Leis do Império do Brasil, Rio de Janeiro, parte 2, p. 207-250, 1877. Disponível em: $<$ http://www2.camara.leg.br/atividade-legislativa/legislacao/publicacoes/doimper io/colecao2.html>Acesso em: Mar. 2017.

BRASIL. Decreto $n^{\circ} 10.044$, de 22 de Setembro de 1888. Coleção de Leis do Império do Brasil, Rio de Janeiro, parte 2, v. 2, p. 284, 1889. Disponível em: < http://www2.camara.leg.br/atividade-legislativa/legislacao/publicacoes/doimperi o/colecao8.html> Acesso em: Jun. 2017. 
BRASIL. Decreto $n^{\circ} 10.044$, de 22 de Setembro de 1888. Coleção de Leis do Império do Brasil, Rio de Janeiro, v. 2, parte 2, p. 284, 1889. Disponível em:< http:/www2.camara.leg.br/atividade-legislativa/legislacao/publicacoes/doimperi o/colecao8.html> Acesso em: Jun. 2017.

BRASIL. Decreto $n^{\circ}$ 2.230, de 10 de Fevereiro de 1896. Coleção das Leis da República, Rio de Janeiro, parte 2, p. 156-271, 1897. Disponível em:< http://www2.camara.leg.br/atividade-legislativa/legislacao/publicacoes/republic a /colecao1.html> Acesso em: Mar. 2017

BRASIL. Decreto $n^{\circ} 255$ de 29 de novembro de 1842. Coleção das Leis do Império do Brasil, Rio de Janeiro, parte 2, p. 494-499, 1843. Disponível em: $<$ http://www2.camara.leg.br/atividade-legislativa/legislacao/publicacoes/doimper io/colecao4.html>Acesso em: Mar. 2017.

BRASIL. Decreto $n^{\circ} 399$ de 21 de dezembro de 1844. Coleção das Leis do Império do Brasil, Rio de Janeiro, parte 1, p. 267-316, 1845. Disponível em: $<$ http://www2.camara.leg.br/atividade-legislativa/legislacao/publicacoes/doimpe rio/colecao4.html>Acesso em: Mar. 2017.

BRASIL. Lei $n^{o}$ 4.273, de 01 de fevereiro de 1921. Disponível em: $<$ http://legis.senado.gov.br/legislacao/ListaPublicacoes.action> Acesso em: Jun. 2017.

COELHO, M. J. A. Memória histórica da província de Santa Catharina. Desterro: Tipografia de J. J. Lopes, 1856.

DIRETORIA GERAL DOS CORREIOS. Relatório da Diretoria Geral dos Correios do ano de 1918. Rio de Janeiro: Tipografia Martins de Araújo, 1919.

DIRETORIA GERAL DOS CORREIOS. Relatório da Diretoria Geral dos Correios do ano de 1921, apresentado pelo diretor geral Clodomiro Pereira da Silva ao Ministro da Viação e Obras Públicas Engenheiro José Pires do Rio. Rio de Janeiro: Tipografia da Diretoria Geral dos Correios, 1922.

DIRETORIA GERAL DOS CORREIOS. Relatório da Diretoria Geral dos Correios do ano de 1922, apresentado pelo diretor geral Severino Henrique de Lucena Neiva ao Ministro da Viação e Obras Públicas Francisco Sá. Rio de Janeiro: Tipografia da Diretoria Geral dos Correios, 1923.

DIRETORIA GERAL DOS CORREIOS. Relatório da Diretoria Geral dos Correios do ano de 1924, apresentado pelo diretor geral Severino Henrique de Lucena Neiva ao Ministro da Viação e Obras Públicas Francisco Sá. Rio de Janeiro: Tipografia da Diretoria Geral dos Correios, 1925. 
DIRETORIA GERAL DOS CORREIOS. Relatório da Diretoria Geral dos Correios do ano de 1925, apresentado pelo diretor geral Severino Henrique de Lucena Neiva ao Ministro da Viação e Obras Públicas Francisco Sá. Rio de Janeiro: Tipografia da Diretoria Geral dos Correios, 1926.

DIRETORIA GERAL DOS CORREIOS. Relatório da Diretoria Geral dos Correios do ano de 1927, apresentado pelo diretor geral Severino Henrique de Lucena Neiva ao Ministro da Viação e Obras Públicas Victor Konder. Rio de Janeiro: Tipografia da Diretoria Geral dos Correios, 1928.

DIRETORIA GERAL DOS CORREIOS. Relatório da Diretoria Geral dos Correios do ano de 1928, apresentado pelo diretor geral Severino Henrique de Lucena Neiva ao Ministro da Viação e Obras Públicas Victor Konder. Rio de Janeiro: Tipografia da Diretoria Geral dos Correios, 1929.

DIRETORIA GERAL DOS CORREIOS. Relatório da Diretoria Geral dos Correios do ano de 1930, apresentado pelo diretor geral Geonisio Curvello de Mendonça ao Ministro da Viação e Obras Públicas José Américo de Almeida. Rio de Janeiro: Tipografia da Diretoria Geral dos Correios, 1931.

DIRETORIA GERAL DOS CORREIOS. Relatório dos serviços dos correios apresentado pelo diretor geral Antonino Pires de Souza em 1900. Rio de Janeiro: Tipografia da Tribuna, 1901.

DIRETORIA GERAL DOS CORREIOS. Relatório dos serviços dos correios apresentado pelo diretor geral Luiz Betim Paes Leme em 1902. Rio de Janeiro: Imprensa Nacional, 1903.

DIRETORIA GERAL DOS CORREIOS. Relatório dos serviços dos correios apresentado pelo diretor geral Joaquim Carneiro de Miranda e Horta em 1904. Rio de Janeiro: Imprensa Nacional, 1905.

DIRETORIA GERAL DOS CORREIOS. Relatório dos serviços dos correios apresentado pelo diretor geral Joaquim Carneiro de Miranda e Horta ao Ministro da Viação e Obras Públicas Miguel Calmon du Pin e Almeida em 1906. Rio de Janeiro: Imprensa Nacional, 1907.

DIRETORIA GERAL DOS CORREIOS. Relatório dos serviços dos correios apresentado pelo diretor geral Joaquim Carneiro de Miranda e Horta ao Ministro da Viação e Obras Públicas Miguel Calmon du Pin e Almeida em 1908. Rio de Janeiro: Imprensa Nacional, 1909. 
DIRETORIA GERAL DOS CORREIOS. Relatório dos serviços dos correios apresentado pelo diretor geral Joaquim Ignácio Tostá ao Ministro da Viação e Obras Públicas Francisco Sá em 1909. Rio de Janeiro: Imprensa Nacional, 1910.

DIRETORIA GERAL DOS CORREIOS. Relatório dos serviços dos correios apresentado pelo diretor geral Ernesto Lyrio de Siqueira ao Ministro da Viação e Obras Públicas em 1912. Rio de Janeiro: Imprensa Nacional, 1913.

GOULARTI FILHO, A. Agências e Linhas dos Correios na Integração do Território Catarinense no Século XIX. In: Revista Estudos Econômicos, São Paulo, v. 47, n. 2, p. 395-428, 2017.

GOULARTI FILHO, A. Portos, ferrovias e navegações em Santa Catarina. Florianópolis: Ed. UFSC, 2013.

GOULARTI FILHO, A. Origem e crescimento do capital industrial (1880-1945). In: Formação econômica de Santa Catarina. Florianópolis: Ed. UFSC, 2016.

MATtOS, J. A. Colonização do estado de Santa Catharina: dados históricos e estatísticos 1640-1916. Florianópolis: Tipografia do Dia, 1917.

MINISTÉRIO DA VIAÇÃO E OBRAS PÚBLICAS. Boletim: Publicação Oficial Quatro N.9 de janeiro a junho de 1912. Rio de Janeiro: Imprensa Nacional, 1916.

ROSÁRIO, I. O. Três séculos e meio da história postal brasileira (1500-1843). Rio de Janeiro: ECT, 1993.

SILVA, Z. P. da. Oeste catarinense. Rio de Janeiro: Laemmert, 1950.

XAVIER, A. Xapecó. In: MINISTÉRIO DA GUERRA. O centenário do Marechal Bormann. Rio de Janeiro: Gráfica Laemmert, 1944. 


\section{Anexos}

Anexo 1 - Linhas postais em Santa Catana até o ano de 1905

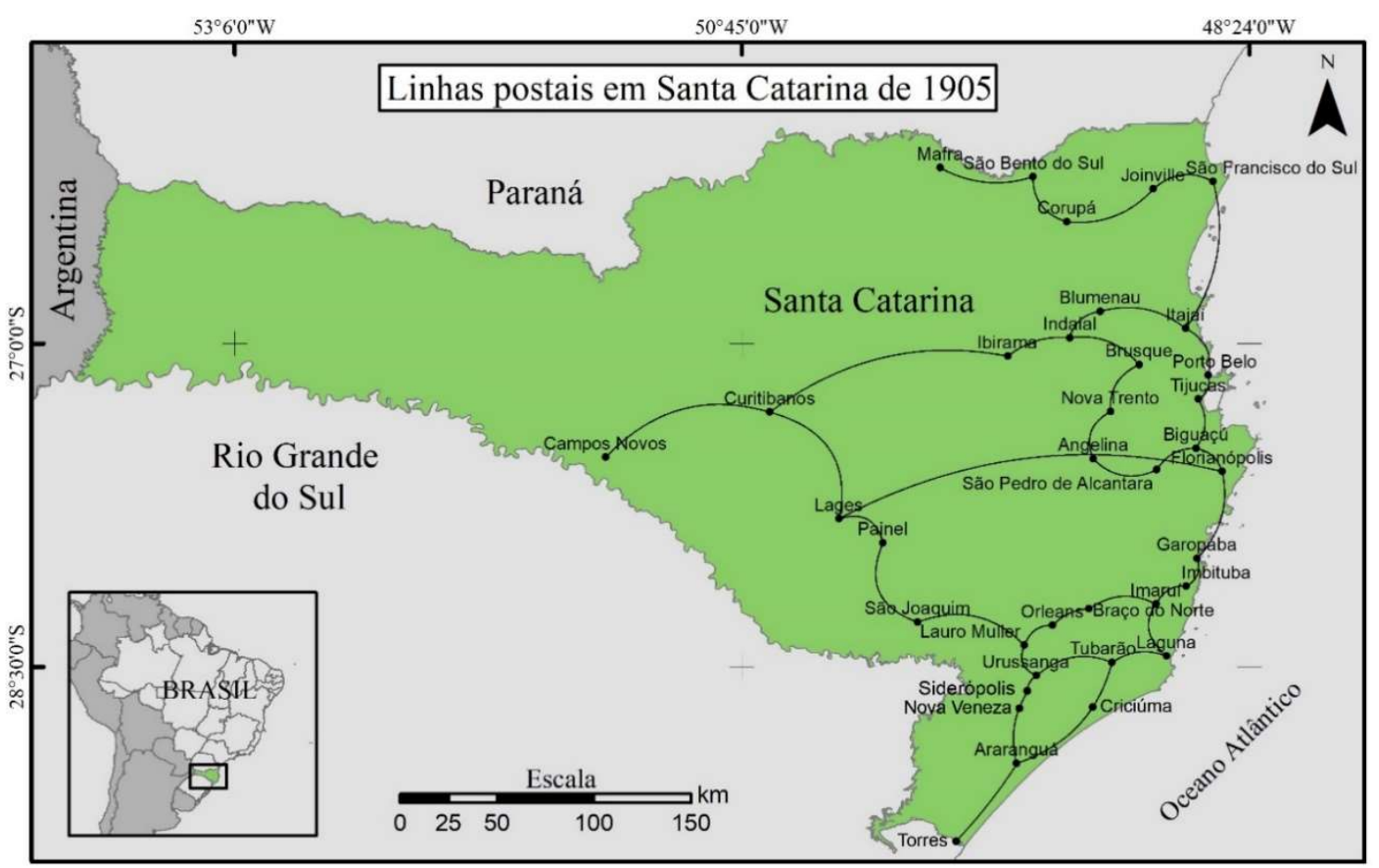

Anexo 2 - Linhas postais em Santa Catarina até o ano de 1910

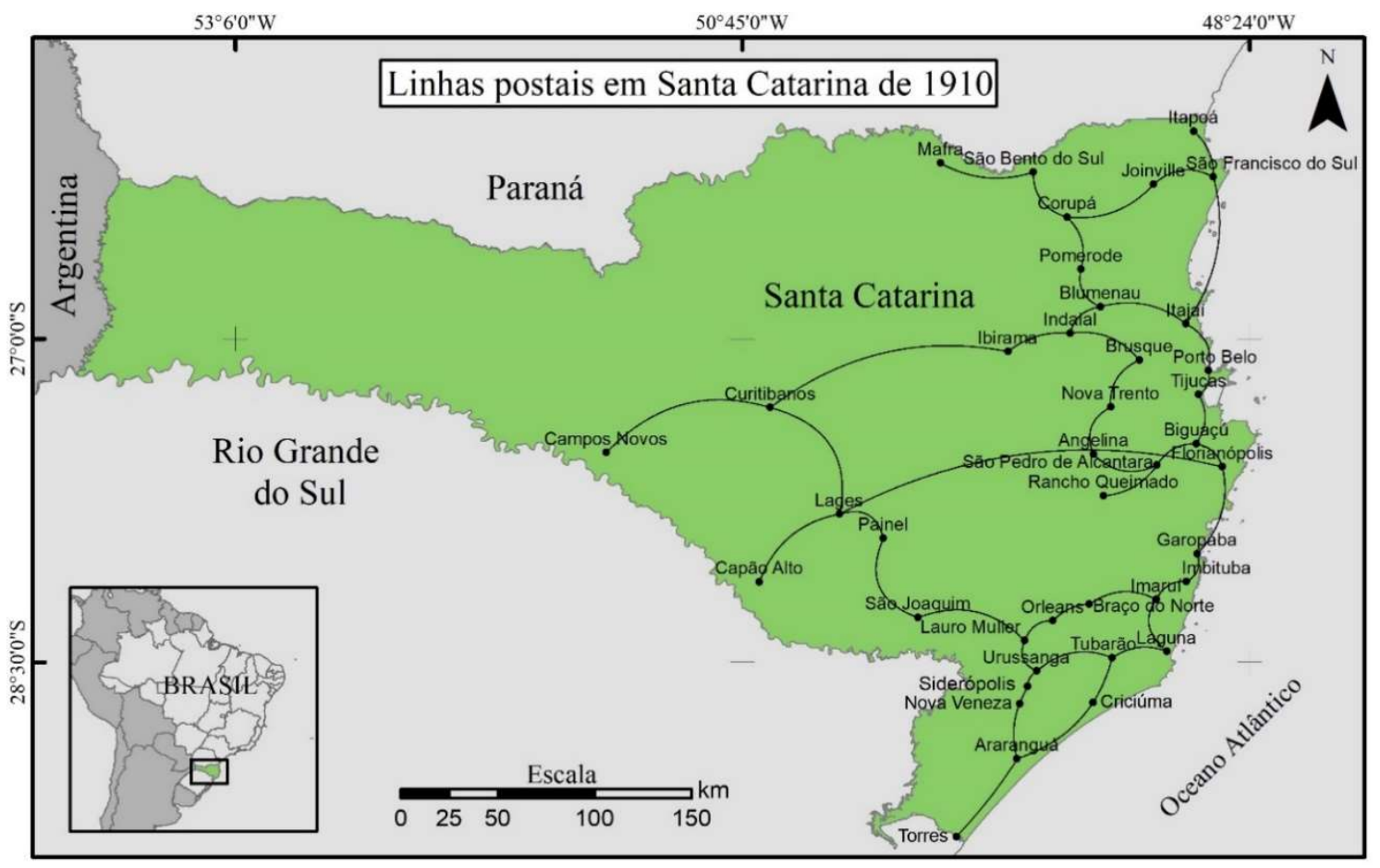




\section{Anexo 3 - Linhas postais em Santa Catarina até o ano de 1915}

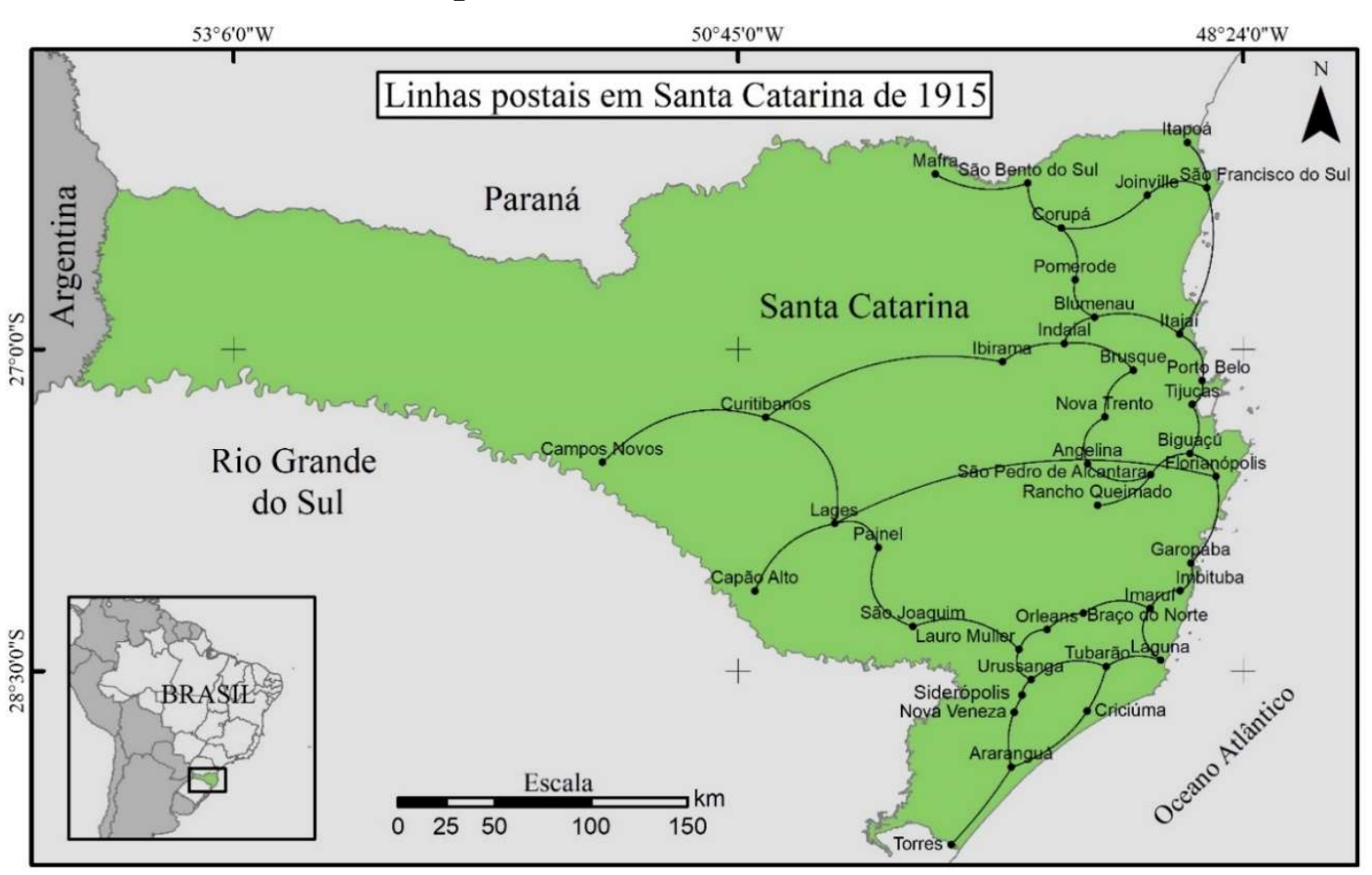

Anexo 4 - Linhas postais em Santa Catarina até o ano de 1920

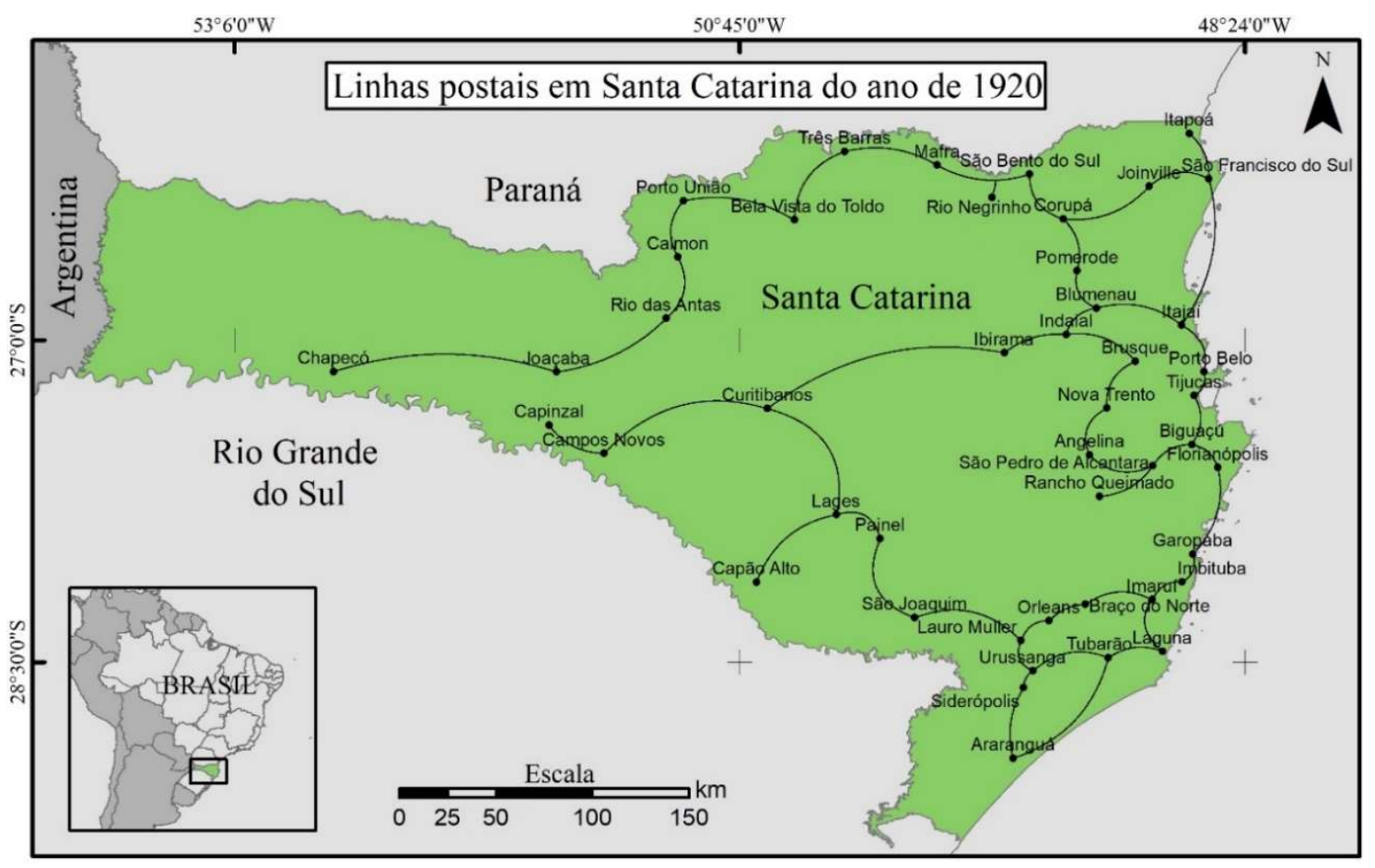




\section{Anexo 5 - Linhas postais em Santa Catarina até o ano de 1925}

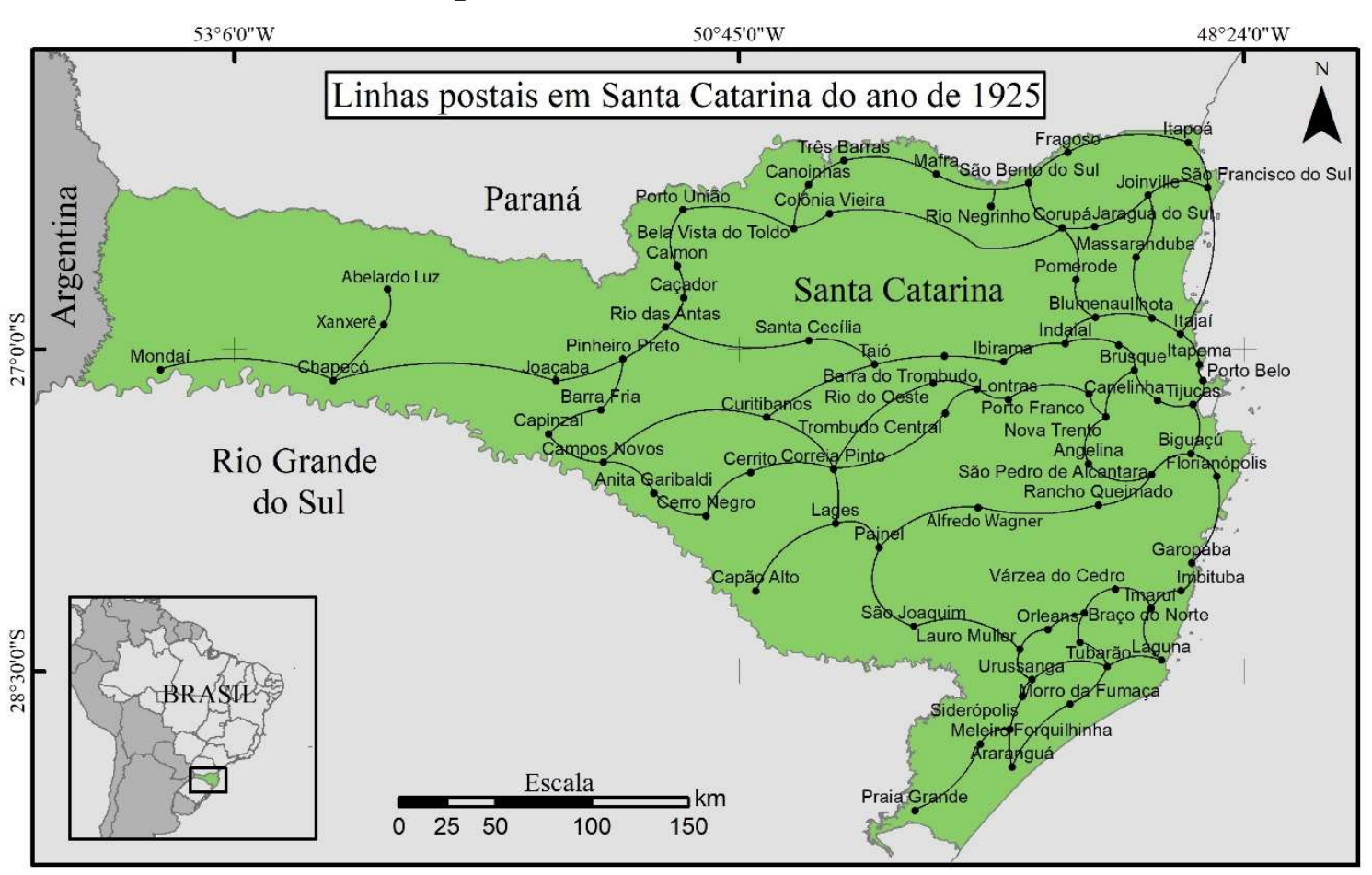

Anexo 6 - Linhas postais em Santa Catarina até o ano de 1930

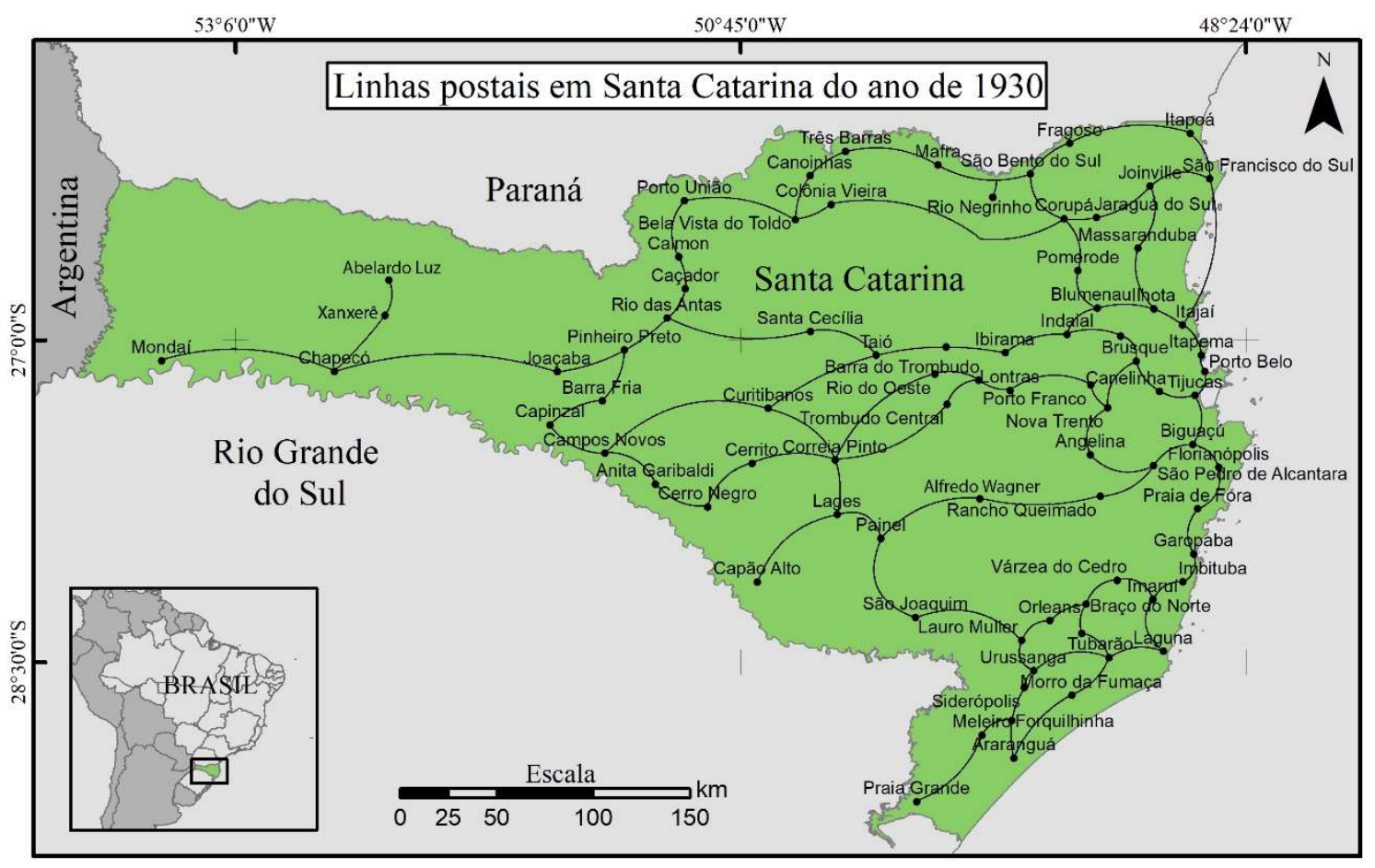

